\title{
Radar Observations of Arctic Bird Migration at the Northwest Passage, Canada
}

\author{
GUDMUNDUR A. GUDMUNDSSON, ${ }^{1}$ THOMAS ALERSTAM, ${ }^{2}$ MARTIN GREEN ${ }^{2}$ and ANDERS HEDENSTRÖM ${ }^{2}$
}

\author{
(Received 18 January 2001; accepted in revised form 6 June 2001)
}

\begin{abstract}
Bird migration was recorded by tracking radar and visual observation at 23 sites in the region of the Northwest Passage, between Baffin Island and Herschel Island in the Beaufort Sea. The studies took place during a ship-based expedition from 29 June to 3 September 1999. A total of 692 tracks (average duration $160 \mathrm{~s}$ ) of bird flocks on postbreeding migration were recorded. Eastward migration was widespread, with the highest intensities at three sites in the southeastern Beaufort Sea. Mainly shorebirds were responsible for these movements, migrating along routes similar to great circles towards Nova Scotia and other parts of the Atlantic coast of North America (whence they depart on transoceanic flights towards South America). Some of the birds in this migration system probably originated from Siberia, as indicated by high-altitude eastward migration at a site $100 \mathrm{~km}$ north of the coast in the Beaufort Sea. Another category of eastward migrants consisted of jaegers, terns, and red phalaropes traveling towards the Davis Strait region and into the Atlantic Ocean. Southward migration was recorded at Baffin Island. A westward migration was pronounced at King William Island (with simultaneous eastward migration) and Amundsen Gulf, while northward movements were important at Banks Island and Melville Island. Apart from westward molt migration of common eiders at Amundsen Gulf, the westward and northward tracks reflected mainly jaegers, terns, gulls, and red phalaropes. These birds were probably making northward flights to exploit pelagic food resources in waters where the ice had recently broken up before their westward migratory exodus from the Arctic region towards the Pacific Ocean. The mean altitude of migration was $793 \mathrm{~m}$, with $27 \%$ of all tracks above $1000 \mathrm{~m}$ and a maximum height of $3.95 \mathrm{~km}$. The altitude distribution was clearly lower than those of the corresponding migration in Siberia and the shorebird migration at Nova Scotia. The average ground speed $(14.9 \mathrm{~m} / \mathrm{s})$ was only slightly faster than the mean air speed $(13.8 \mathrm{~m} / \mathrm{s}$ ), and migrants gained in speed from the winds (ground speed exceeding air speed) in only $55 \%$ of all cases. This means that wind assistance in the study area was much less pronounced than that documented for the migrants in Siberia and Nova Scotia. Bird migration at the Northwest Passage may be characterized by, on average, lower altitudes, less favorable winds, shorter flight steps, and a more widespread accessibility to stopover sites than migration at the Northeast Passage.
\end{abstract}

Key words: Arctic birds, bird flight, bird migration, Canadian Arctic, Northwest Passage, Nunavut, orientation, radar

RÉSUMÉ. On a enregistré la migration aviaire par observations effectuées à l'oeil nu et au radar de poursuite sur 23 sites localisés dans la zone du passage du Nord-Ouest, entre l'île de Baffin et l'île Herschel dans la mer de Beaufort. L'étude s'est déroulée du 29 juin au 3 septembre 1999, durant une expédition navale. On a enregistré un total de 692 poursuites (durée moyenne 160 s) de bandes d'oiseaux effectuant leur migration post-reproductrice. La migration vers l'est était généralisée, avec la plus forte intensité à trois sites dans la mer de Beaufort sud-orientale. Un grand nombre d'oiseaux de rivage prenaient part à ces mouvements, suivant des routes migratoires semblables à des routes orthodromiques vers la Nouvelle-Écosse et d'autres régions de la côte atlantique de l'Amérique du Nord (d'où ils débutent leur vols transocéaniques à destination de l'Amérique du Sud). Certains parmi les oiseaux de ce système migratoire venaient probablement de Sibérie, comme l'indique la migration vers l'est à haute altitude observée à un site localisé à $100 \mathrm{~km}$ au nord du rivage de la mer de Beaufort. Une autre catégorie de migrateurs se dirigeant vers l'est comprenait des labbes, des sternes et des phalaropes à bec large voyageant vers la région du détroit de Davis et l'océan Atlantique. À l'île de Baffin, on a observé une migration vers le sud. Une migration vers l'ouest était très nette à l'île du RoiGuillaume (avec une migration simultanée vers l'est) ainsi que dans le golfe Amundsen, tandis que de vastes mouvements en direction du nord avaient lieu aux îles Banks et Melville. Mis à part la migration vers l'ouest effectuée durant la mue de l'eider à duvet au golfe Amundsen, les routes vers l'ouest et le nord reflétaient surtout la présence de labbes, de sternes, de mouettes et de phalaropes à bec large. Ces oiseaux effectuaient probablement des vols en direction du nord pour exploiter les ressources alimentaires pélagiques des eaux dont la banquise s'était récemment démantelée, avant de reprendre leur exode migratoire vers l'ouest depuis les régions arctiques en direction de l'océan Pacifique. L'altitude moyenne de la migration était de $793 \mathrm{~m}$, avec 27 p. cent de toutes les routes situées au-dessus de $1000 \mathrm{~m}$ et une altitude maximale de 3,95 km. La distribution verticale était nettement plus basse que celles des migrations correspondantes en Sibérie et de la migration des oiseaux de rivage en NouvelleÉcosse. La vitesse sol moyenne (14,9 m/s) était à peine plus rapide que la vitesse air moyenne $(13,8 \mathrm{~m} / \mathrm{s})$ et, dans seulement 55 p. cent des cas, les migrateurs gagnaient de la vitesse avec les vents (la vitesse sol étant supérieure à la vitesse air). Ce qui signifie que, dans la zone d'étude, l'assistance éolienne est beaucoup moins prononcée que celle documentée pour les migrateurs en Sibérie

${ }^{1}$ Icelandic Institute of Natural History, P.O. Box 5320, IS-125 Reykjavik, Iceland; mummi@ ni.is

${ }^{2}$ Department of Animal Ecology, Lund University, Ecology Building, SE-223 62 Lund, Sweden; Thomas.Alerstam@ekol.lu.se, Martin.Green@zooekol.lu.se, Anders.Hedenstrom@zooekol.lu.se

(C) The Arctic Institute of North America 
et en Nouvelle-Écosse. On pourrait caractériser la migration des oiseaux dans le passage du Nord-Ouest comme s'effectuant en moyenne à de plus faibles altitudes, avec des vents moins favorables, des étapes de vol plus courtes et un accès plus généralisé à des sites d'escale que la migration au passage du Nord-Est.

Mots clés: oiseaux arctiques, vol d'oiseaux, vol d'oiseaux migrateurs, Arctique canadien, passage du Nord-Ouest, Nunavut, orientation, radar

Traduit pour la revue Arctic par Nésida Loyer.

\section{INTRODUCTION}

The migration performance of many Arctic birds is remarkable, not only in the sense that they carry out the longest journeys among birds, but also because of their travel and orientation capabilities under complex polar conditions.

Radar is an important tool in bird migration studies for recording bird movements that are inaccessible to visual observation techniques because of high altitudes, poor visibility, clouds, or darkness. Radar observations combined with complementary visual field data give the most complete picture of the birds' migration pattern (flight directions, altitudes, and speeds) at a given site and on a given occasion.

Arctic bird migration patterns (cf. Johnson and Herter, 1990) have been explored by radar studies in different regions, such as Alaska (Flock, 1972, 1973) and the Yukon coast of the Beaufort Sea (Richardson and Johnson, 1981; Johnson and Richardson, 1982), Greenland (Alerstam et al., 1986), Iceland (Gudmundsson, 1993), in the central Arctic Ocean close to the geographic North Pole (Gudmundsson and Alerstam, 1998a), and at a large number of sites between $50^{\circ} \mathrm{E}$ and $170^{\circ} \mathrm{E}$ along the Northeast Passage in Eurasia (Alerstam and Gudmundsson, 1999a, b). In addition, Richardson (1979) recorded the autumn migration over Nova Scotia and New Brunswick of shorebirds originating mainly from the Canadian Arctic and departing across the Atlantic Ocean towards South America.

However, radar studies are lacking from a vast region in the Canadian Arctic at the Northwest Passage between Davis Strait/Baffin Bay and the Beaufort Sea. The pattern and process of bird migration in this region are of foremost interest, as they can reveal migratory divides between populations from the Pacific and Atlantic migration systems. Radar studies could also help us to investigate whether the birds' migration routes conform to great circles (orthodromes), which are significantly shorter than rhumb lines (loxodromes) at polar latitudes, and to evaluate the observed flight routes in relation to the orientation difficulties encountered in this area because of extreme geomagnetic field conditions close to the North Magnetic Pole.

The region of the Northwest Passage, which is an immense Arctic archipelago with a maze of highly variable terrestrial, limnic, and marine conditions, has a spectacular history of human immigrations and adaptations (e.g., McGhee, 1996; Schledermann, 1996) as well as of Arctic exploration and expeditions (e.g., Mirsky, 1970; Savours, 1999). The travels of birds in this region is, of course, an altogether different subject, but the intricate and dramatic environmental conditions also make the Northwest Passage a region of very special interest within the field of bird migration and orientation. Information from this region will be of key importance for understanding the evolutionary process behind the migration systems of Arctic birds.

In this study, we placed tracking radar on board the Canadian Coast Guard icebreaker Louis S. St-Laurent to record the postbreeding bird migration during an expedition along the Northwest Passage in July and August 1999. Radar observations were carried out at a large number of sites during the journey from Davis Strait to the Beaufort Sea and back again. The outward and return journeys took place along different routes, and the return journey included a visit to the current position of the North Magnetic Pole (Molau et al., 1999; Grönlund, 2000). Our way of conducting these studies was essentially the same as on a previous expedition along the Northeast Passage in 1994 (Alerstam and Gudmundsson, 1999a; Alerstam and Jönsson, 1999), and one important objective for the present study at the Northwest Passage was to compare bird migration between these two major tundra regions in the Old World and New World, respectively.

This paper presents our radar results and field observations for each study site and summarizes the distributions of directions, altitudes, and speeds of bird migration over the whole region. We evaluate observed flight directions and routes in relation to the migration systems of shorebirds, jaegers, and terns in the New World (e.g., Morrison, 1984) and compare altitudes and speeds with the corresponding information for tundra migrants at the Northeast Passage (Alerstam and Gudmundsson, 1999a) and for shorebirds at Nova Scotia (Richardson, 1979). In separate papers, we have evaluated the possible orientation mechanisms by analyzing observed flight directions in relation to trajectories predicted from different celestial and geomagnetic orientation cues (Alerstam et al., 2001); examined the effect of wind drift on the birds' flight directions (Green et al., unpubl. data); and analyzed the variation in the birds' air speed in relation to predictions based on flight mechanical theory (Hedenström et al., unpubl. data).

\section{OBSERVATION SITES AND METHODS}

Tracking radar observations with complementary field studies were carried out at 23 different sites during the 
TABLE 1. Results from tracking-radar studies of bird migration during the Tundra Northwest 1999 expedition. The sites (A-Z) where radar observations were conducted are shown on the map in Figure 1. The table shows the number of radar tracks of migrating birds recorded at each site, as well as the number of tracks of helium balloons recorded for wind measurements. The total operation time of the radar at each site is also given.

\begin{tabular}{|c|c|c|c|c|c|c|c|c|}
\hline Site & Locality & $\begin{array}{l}\text { Latitude } \\
\text { deg. } \mathrm{N}\end{array}$ & $\begin{array}{c}\text { Longitude } \\
\text { deg. W }\end{array}$ & Date & $\begin{array}{l}\text { No. of } \\
\text { wind tracks }\end{array}$ & $\begin{array}{c}\text { No. of } \\
\text { bird tracks }\end{array}$ & $\begin{array}{l}\text { No. of } \\
\text { radar hours }\end{array}$ & $\begin{array}{c}\text { Bird tracks } \\
\text { per hour }\end{array}$ \\
\hline A & Iqaluit & 63.7 & 68.5 & 29 June & 3 & 3 & 8 & 0.4 \\
\hline B & Ungava & 62.5 & 73.6 & 1-2 July & 0 & 0 & 3 & 0.0 \\
\hline $\mathrm{C}$ & Melville Peninsula & 67.7 & 81.4 & 5-7 July & 5 & 6 & 29 & 0.2 \\
\hline $\mathrm{D}$ & Somerset Island & 72.7 & 93.0 & 9-11 July & 6 & 10 & 17.5 & 0.6 \\
\hline $\mathrm{E}$ & S Bathurst Island & 75.0 & 98.3 & 13-14 July & 6 & 7 & 26 & 0.3 \\
\hline $\mathrm{F}$ & N Bathurst Island & 76.6 & 98.1 & 15-16 July & 3 & 2 & 23 & 0.1 \\
\hline G & Larsen Sound & 70.5 & 97.9 & 19 July & 1 & 4 & 6 & 0.7 \\
\hline $\mathrm{H}$ & King William Island & 69.4 & 99.2 & $20-22$ July & 10 & 50 & 25.5 & 2.0 \\
\hline $\mathrm{J}$ & Wollaston Peninsula & 69.3 & 115.0 & $23-25$ July & 7 & 25 & 26 & 1.0 \\
\hline $\mathrm{K}$ & Amundsen Gulf & 69.8 & 122.2 & 26-28 July & 4 & 73 & 24 & 3.0 \\
\hline $\mathrm{L}$ & S Banks Island & 71.7 & 124.0 & $28-29$ July & 6 & 33 & 22 & 1.5 \\
\hline M & Tuktoyaktuk & 69.8 & 133.3 & 31 July-1 Aug, 6-7 August & 13 & 124 & 35.5 & 3.5 \\
\hline $\mathrm{N}$ & Beaufort Sea & 70.5 & 139.0 & $2-3$ August & 6 & 34 & 22 & 1.5 \\
\hline $\mathrm{O}$ & Herschel Island & 69.6 & 139.5 & 3-5 August & 9 & 144 & 33.5 & 4.3 \\
\hline $\mathrm{P}$ & Baillie Islands & 70.6 & 128.4 & $7-8$ August & 2 & 1 & 10 & 0.1 \\
\hline $\mathrm{R}$ & N Banks Island & 73.7 & 115.5 & 10-12 August & 7 & 78 & 33.5 & 2.3 \\
\hline $\mathrm{S}$ & Melville Island & 74.9 & 108.0 & $13-15$ August & 7 & 32 & 30 & 1.1 \\
\hline $\mathrm{T}$ & Ellef Ringnes Island & 79.0 & 104.8 & 18-20 August & 5 & 3 & 42.5 & 0.1 \\
\hline $\mathrm{U}$ & S Ellesmere Island & 76.3 & 87.4 & $22-23$ August & 3 & 7 & 14.5 & 0.5 \\
\hline V & SE Devon Island & 74.5 & 82.5 & $25-26$ August & 0 & 2 & 17 & 0.1 \\
\hline W & Pond Inlet & 72.7 & 78.0 & 27 August & 1 & 0 & 5 & 0.0 \\
\hline $\mathrm{X}$ & N Baffin Island & 71.7 & 71.9 & 28 August & 0 & 0 & 2 & 0.0 \\
\hline Y & E Baffin Island & 68.6 & 66.3 & $30-31$ August & 4 & 23 & 19 & 1.2 \\
\hline \multirow[t]{2}{*}{ Z } & Iqaluit & 63.7 & 68.5 & 3 September & 5 & 31 & 19 & 1.6 \\
\hline & Total, all sites & & & & 113 & 692 & 493.5 & 1.4 \\
\hline
\end{tabular}

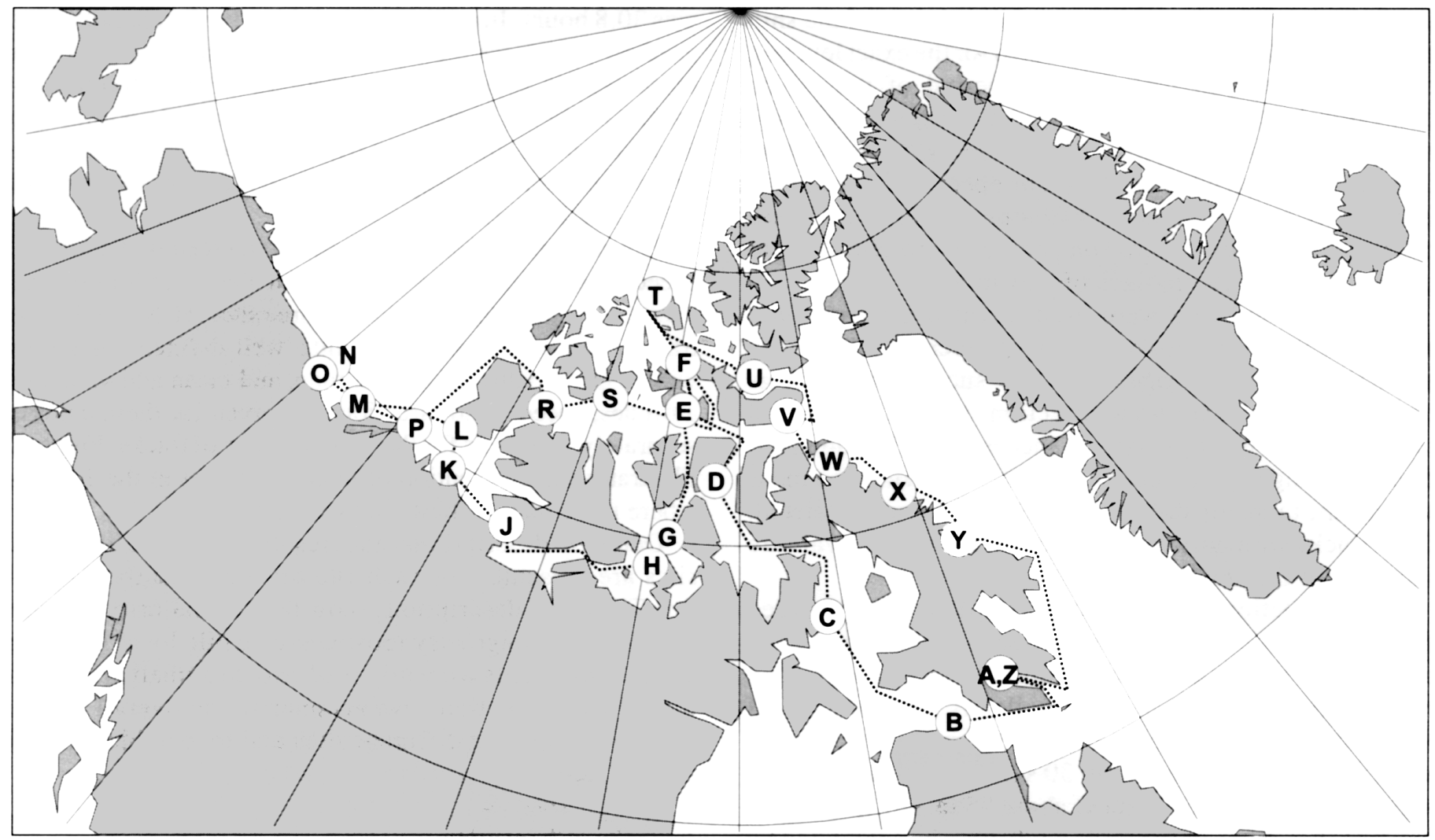

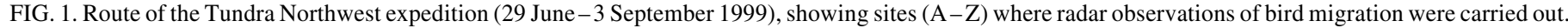
Locations, dates, and general radar information for each site are given in Table 1. 
expedition "Tundra Northwest 1999" (Molau et al., 1999; Grönlund, 2000), as shown in Table 1 and Figure 1. Practically all radar observations were carried out when the ship was stationary in pack ice or open water, mostly $2-8 \mathrm{~km}$ from the nearest tundra shore, except at two sites (M and N; Table 1), which were about 27 and $100 \mathrm{~km}$ away from the coast, respectively. Targets that were tracked included both individual birds (some small birds like passerines could also be detected by the radar) and flocks, with flocks clearly dominating, judging by the echo signatures seen by the radar operator. Visual observations were made from the ship and during field visits to the tundra camps, and we obtained much supplementary field data from ornithologists participating in the expedition and working at the field camps at each site.

The tracking radar (PV882; $3 \mathrm{~cm}$ wavelength, $200 \mathrm{~kW}$ peak power, $0.25 / 1.0 \mu$ s pulse duration, and $1.5^{\circ}$ nominal pencil beam width) was placed above the helicopter deck on the Canadian Coast Guard icebreaker Louis S. St-Laurent, with the antenna approximately $21 \mathrm{~m}$ above sea level. The accuracy of radar measurements was limited to $0.06^{\circ}$ in angle (azimuth, elevation) and $10 \mathrm{~m}$ in range. The minimum and maximum ranges for radar tracking of birds were about $1 \mathrm{~km}$ and $15 \mathrm{~km}$, respectively. Range, elevation, and bearing to the target were stored by computer every $2 \mathrm{~s}$ while the radar was recording a target in automatic tracking mode. Simultaneous computer readings of the ship's gyrocompass and GPS were made every $2 \mathrm{~s}$, and these data were used to correct for the direction and movement of the ship during all trackings. We also corrected for the exact leveling of the ship at each new site and period of radar data collection by calibrating the radar elevation against the horizon in different compass directions (a video camera on the radar antenna allowed the radar operator to locate the horizon as well as weather balloons, cf. below). These calibration data were stored on computer and later used to correct the primary readings of elevations.

The corrected data were used to calculate horizontal and vertical coordinates of the targets every $2 \mathrm{~s}$. Positions and heights were averaged over five successive readings and used to calculate track direction, ground speed, and vertical speed of the target in successive $10 \mathrm{~s}$ intervals. Each tracking was inspected, and intervals when the radar was off the target or shifted to another target were deleted. Only tracks with data from at least three $10 \mathrm{~s}$ intervals are included in this analysis.

Wind direction and speed at low altitude were recorded from an anemometer (29 $\mathrm{m}$ above sea level) on board the ship, while winds at higher altitudes were measured by radar tracking of helium-filled balloons. On the basis of these trackings, wind profiles were determined with mean wind directions and speeds in $30 \mathrm{~s}$ intervals, which corresponded to altitudinal strata of about $75 \mathrm{~m}$. Air speeds and heading directions of the birds could then be calculated by vector subtraction of horizontal wind velocities at the altitudes where the birds were flying (wind data were interpolated to the exact altitude of the birds for each $10 \mathrm{~s}$ interval). Air speed and heading were calculated for cases where wind data were available within two hours from the time of the bird tracking.

On the basis of the data for $10 \mathrm{~s}$ intervals, the overall mean altitude, speeds (vertical, ground, air, and wind speeds), and directions (track, heading, and wind direction) were calculated for each track of migrating birds. Mean directions and the scatter of directions for different samples of tracks have been calculated as mean vector directions and mean vector lengths (r), respectively (Batschelet, 1981). These overall means are used for the present evaluation. Times were recorded in UTC (= GMT) and calculated into exact local times according to the longitude of the relevant site.

Our methods were virtually the same as those used in an earlier study along the Northeast Passage (Alerstam and Gudmundsson, 1999a), allowing a direct comparison of the results between the two studies.

\section{RESULTS}

Radar operation took place at 23 different sites (A-Z, the first and final site being the same) along the expedition route (Fig. 1, Appendix) during 493.5 hours. In total, 692 radar tracks of birds were recorded at 20 of these sites (Table 1). These tracks lasted for 30-1410 s, with an overall mean duration of $160 \mathrm{~s}$. The total bird tracking time was 30.8 hours. In addition to tracking birds, the radar was used on 113 occasions to track weather balloons in order to determine wind direction and speed at different altitudes (Table 1). Reliable wind measurements within two hours from the time of bird tracks, permitting calculation of air speed and heading direction, were available for 644 of the 692 bird tracks.

The number of tracks and the mean and scatter of altitudes, speeds, and directions at the different sites (and for the total data set) are given in Table 2. For three sites ( $\mathrm{H}, \mathrm{K}$, and $\mathrm{L})$, the tracks have been subdivided into well-defined categories with respect to direction or altitude, and mean and scatter of altitudes, speeds, and directions are given for these cohorts separately as well as for the total samples of tracks. Figure 2 illustrates the distribution of track directions at the 11 sites where more than 10 bird tracks were recorded.

Detailed descriptions and results from the different sites are presented for each site separately in the Appendix. These site descriptions show that the majority of radar tracks reflect migratory movements, while local foraging and resting flights were involved only to a small degree. In the following sections, we summarize the overall results both by comparing different sites and by combining data from all sites.

\section{Intensity of Migration}

The number of bird tracks per hour of radar operation (see Table 1) provides only a very rough estimate of bird 


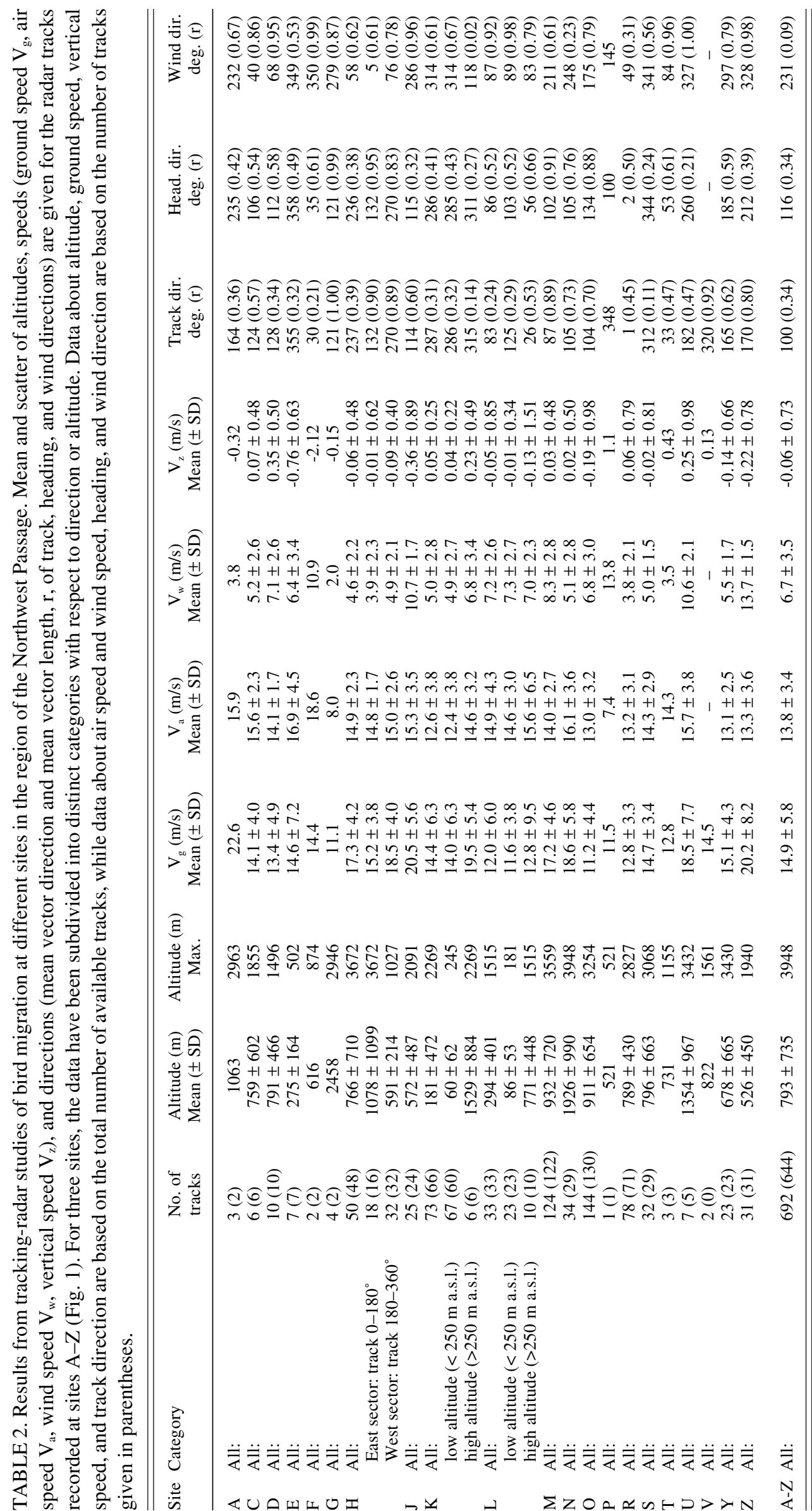

movement intensity (intensive movements are under-estimated, because much radar time is then devoted to tracking rather than to searching), but still reflects the large differences that were observed between different sites. At some sites, a low intensity was associated with adverse weather (sites B and P) or unsuitable local conditions for radar tracking (V and $\mathrm{W}$ ). However, some sites had a remarkably low, almost negligible, bird movement intensity in spite of good radar and weather conditions. This was the situation at the most northerly sites, at Ellef Ringnes ( $\mathrm{T}$ ), Bathurst (E and F), and southern Ellesmere (U) Islands. Bird movements were also extremely sparse at Melville Peninsula (C) and Somerset Island (D). At these two sites, as well as at Bathurst Island (E, F), the sparse movement was perhaps due to the early time of season.

The almost empty skies encountered over the Queen Elizabeth Islands stand in stark contrast to the mass migration taking place over the southeastern Beaufort Sea (M, N, O), while migratory intensity was on a more moderate level at King William Island $(\mathrm{H})$, Wollaston Peninsula (J), Banks Island (R), Melville Island ( $\mathrm{S}$ ), and the southern part of Baffin Island (Y, Z).

Number of tracks per hour of radar operation gives a relative measure of the migration intensity (Table 3). Migration took place at all hours of the day, but the intensity level was lower during the afternoon (local time). This is clearly indicated by the proportion of bird tracks recorded during different periods of the day: 0000 0600: $27 \%, 0600-1200: 30 \%$, $1200-1800: 13 \%$, and $1800-$ 2400: $30 \%$ (based on all 692 tracks). Radar operation was 


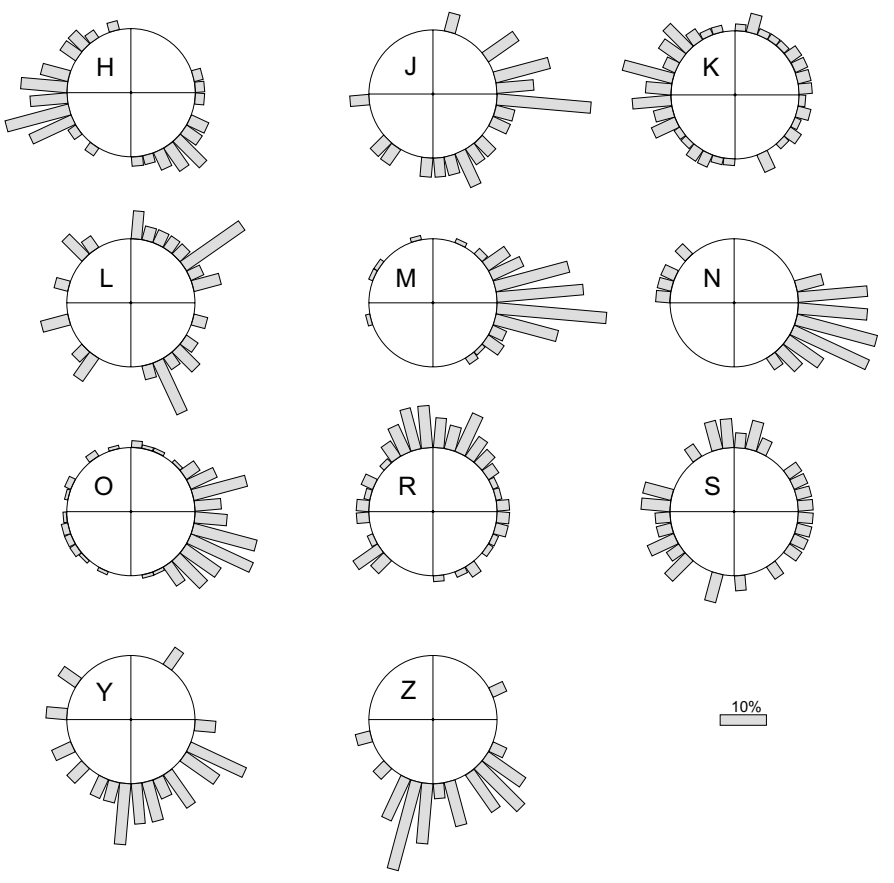

FIG. 2. Distributions of track directions for sites with more than 10 radar tracks. The circular diagrams show the percentage distribution for each site. Site information is given in Table 1 and Figure 1, and information about sample sizes and mean and scatter of directions is in Table 2.

fairly evenly distributed during the different hours of the day (Table 3).

\section{Directions of Migration}

Comparison Between Sites: Circular distributions of track directions are presented in Figure 2 (sites with more than 10 tracks). The proportions of eastward/westward versus northward/southward tracks are plotted in Figure 3 to show similarities and differences between sites with respect to the migratory directions.

As seen from these figures, there was a pronounced concentration of easterly migration at the three Beaufort Sea sites (M, N, O) and at Wollaston Peninsula (J). Easterly directions $\left(0-180^{\circ}\right)$ made up $84-97 \%$ of all track directions at these sites. While the mean direction was almost due east $\left(87^{\circ} ; \mathrm{cf}\right.$. Table 2$)$ at site $\mathrm{M}$, there was a dominance of southeasterly tracks at sites $\mathrm{J}, \mathrm{N}$, and $\mathrm{O}$, where the overall mean directions were $114^{\circ}, 105^{\circ}$, and $104^{\circ}$, respectively (Table 2). A large proportion (73\%) of easterly tracks was recorded also at southern Banks Island (L). However, these easterly movements were rather disparate in character, involving northeasterly high-altitude departures across land as well as southeasterly flights low over the sea. These movements probably bore little relationship to the eastward stream of migration at sites $\mathrm{J}, \mathrm{M}, \mathrm{N}$, and $\mathrm{O}$.

Two of the sites at Baffin Island $(\mathrm{Y}, \mathrm{Z})$ showed a high degree of similarity, with a strong dominance $(87-97 \%)$ of southerly directions. The mean directions at these sites $\left(165^{\circ}\right.$ at $\mathrm{Y}$ and $170^{\circ}$ at $\left.\mathrm{Z}\right)$ showed only a slight easterly deviation from due south (Table 2).
Almost the reverse directional pattern was found at northern Banks Island ( $\mathrm{R})$, where northerly tracks dominated $(73 \%)$ and mean direction was towards due north $\left(1^{\circ}\right)$.

The remaining three sites in Figure 3, King William Island (H), Amundsen Gulf (K), and Melville Island (S), showed a less distinct dominance of migration into any given sector. At site $\mathrm{H}$, there was a well-defined bimodal migration pattern towards southeast and west (Fig. 2). At site K, westerly directions dominated among the movements low over the sea, although the scatter was considerable. At site $\mathrm{S}$, the dispersion of migratory directions was so large that the circular distribution appeared to be uniform or random. One possible explanation is that migration at this site was a mixture of different migratory movements, with preferred track directions towards northerly, westerly, and easterly sectors, respectively (see account for site $S$ in the Appendix).

Eastward Migration: Easterly movements were apparently of regular occurrence over most of the study region, although they were sparse at northerly sites. An easterly migration stream was most pronounced at the Beaufort sites (M, N, and O), but was also distinct at Wollaston Peninsula (J), King William Island (H), and southern Baffin Island ( $\mathrm{Y}$ and $\mathrm{Z}$ ). The mean direction shifted from almost due east at the Beaufort Sea to southeast at King William Island and approaching south at Baffin Island.

Combining the easterly tracks $\left(0-180^{\circ}\right)$ at the three Beaufort Sea sites (M, N, O), the distribution in different subsectors was as follows: $0-30^{\circ}: 2 \% ; 30-60^{\circ}: 5 \% ; 60-$ $90^{\circ}: 33 \% ; 90-120^{\circ}: 42 \% ; 120-150^{\circ}: 17 \%$; and $150-$ $180^{\circ}: 1 \%$, with an overall mean direction of $96^{\circ}(\mathrm{r}=0.90$, $\mathrm{n}=279)$. The easterly tracks at Wollaston Peninsula $(\mathrm{J})$ showed a similar mean direction of $102^{\circ}$ but with a larger scatter $(\mathrm{r}=0.72, \mathrm{n}=21)$. At King William Island $(\mathrm{H})$, the easterly tracks had a well-defined peak in the sector 110 $160^{\circ}$, with a mean of $132^{\circ}(r=0.90, n=18$, cf. Fig. 2). At Baffin Island (Y, Z), the track distributions were shifted farther towards the south, and mean directions were 165$170^{\circ}$ (Fig. 2, Table 2; see southerly movements below).

Easterly tracks were also recorded at several other sites. Although few in number, the easterly movements represented an important proportion of the total migration at these sites. The widespread occurrence and sometimes the high altitudes of these easterly tracks indicate that easterly migration is a regular feature in most parts of the Canadian High Arctic. Hence, movements in the sector 50-180 were recorded both at northern Banks Island $(\mathrm{R} ; \mathrm{n}=16)$ and at Melville Island ( $; ; n=10)$. At southern Ellesmere Island $(\mathrm{U})$, four of the seven tracks were towards the southeast, $129-148^{\circ}$. Additional cases of easterly migration were recorded earlier in the season at Melville Peninsula (C), with three tracks towards $105-111^{\circ}$; at Somerset Island (D), with six tracks scattered between $46^{\circ}$ and $159^{\circ}$; and at Larsen Sound $(\mathrm{G})$, with four tracks towards 118 $128^{\circ}$. 
TABLE 3. Distribution of radar tracks and radar operation time during different hours of the day. Number of radar tracks per hour of operation permits comparison of relative migration intensities at different periods of the day. Data from all observation sites are pooled.

\begin{tabular}{|c|c|c|c|c|c|c|c|c|c|}
\hline Local time & $0000-0300$ & $0300-0600$ & $0600-0900$ & $0900-1200$ & $1200-1500$ & $1500-1800$ & $1800-2100$ & $2100-2400$ & Total \\
\hline No. radar tracks & 99 & 88 & 114 & 94 & 53 & 37 & 103 & 104 & 692 \\
\hline Hours of radar operation & 43.5 & 46.5 & 75 & 68 & 71 & 60.5 & 63.5 & 65.5 & 493.5 \\
\hline No. radar tracks per hour & 2.3 & 1.9 & 1.5 & 1.4 & 0.7 & 0.6 & 1.6 & 1.6 & 1.4 \\
\hline
\end{tabular}

$\%$ West $\left(180-360^{\circ}\right)$

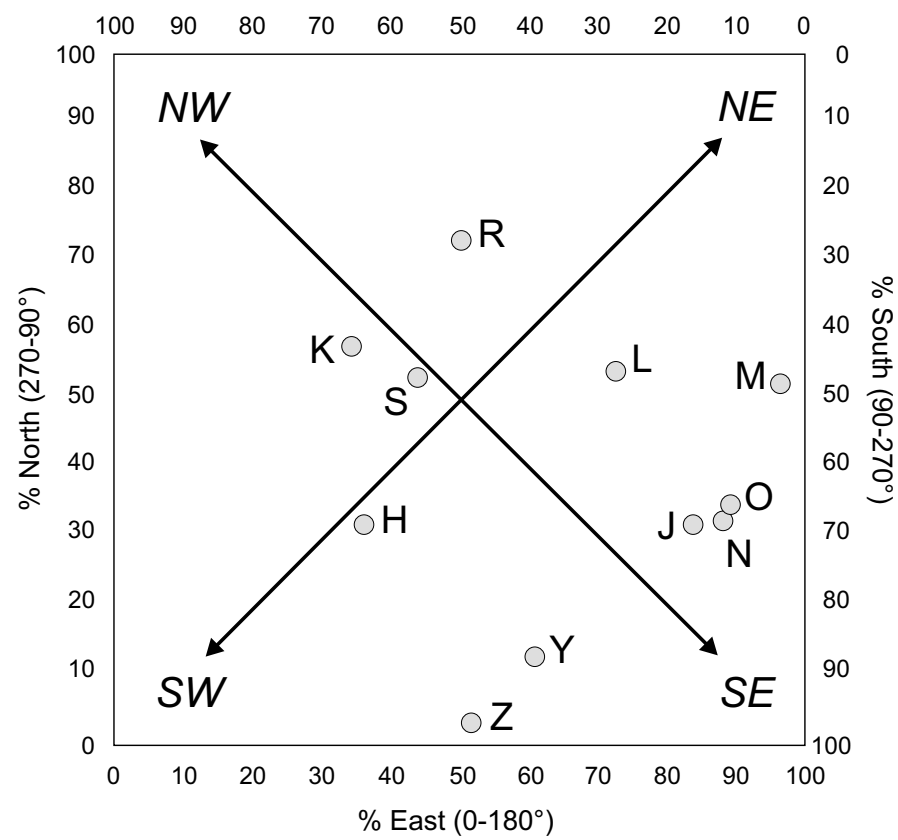

FIG. 3. Diagram comparing the overall directional tendencies for sites with more than 10 radar tracks. The proportion of eastward/westward tracks is plotted in relation to the proportion of northward/southward tracks.

It seems most likely that the easterly movements reflect migration of shorebirds (cf. Appendix), and some easterly radar tracks were identified as shorebird flocks (including one flock of American golden-plover Pluvialis dominica) at the Beaufort Sea sites. According to field observations, the following species were probably most common among these migrants: semipalmated sandpiper Calidris pusilla, American golden-plover, white-rumped sandpiper Calidris fuscicollis, pectoral sandpiper Calidris melanotos, red knot Calidris canutus, and red phalarope Phalaropus fulicarius. Red phalaropes were suspected to be particularly important in the easterly migration recorded early in the season at Melville Peninsula (C) and Somerset Island (D). Several additional shorebird species are also candidates in some of the easterly movements, e.g., buff-breasted sandpiper Tryngites subruficollis, red-necked phalarope Phalaropus lobatus, Baird's sandpiper Calidris bairdii, ruddy turnstone Arenaria interpres, sanderling Calidris $a l b a$, and black-bellied plover Pluvialis squatarola.

The wave of easterly mass migration in the southeasterly Beaufort Sea region, as registered at sites $\mathrm{M}, \mathrm{N}$, and $\mathrm{O}$, lasted from 31 July until 7 August, when it stopped because of adverse winds (see site $\mathrm{P}$ in the Appendix). In total, 279 easterly tracks $\left(0-180^{\circ}\right)$ were recorded during 91 radar hours in this period. One may very provisionally "guesstimate" that as many as 20 000-50 000 shorebirds passed the ship within a frontal width of $10-15 \mathrm{~km}$ during the radar operation time. This guess is based on the assumption that about $10 \%$ of all flocks passing within the frontal width may have been tracked by radar (a realistic estimate, as judged from the proportion of helicopter passages that we picked up inadvertently during our radar operations), and that the average flock size was 10-20 birds. Extrapolating this estimate over a total time period of 7-8 days and a frontal width of $100 \mathrm{~km}$ indicates that the easterly migration of shorebirds in this region was of a huge magnitude, probably involving several hundreds of thousands of birds.

The numbers, directions, and timing of the climbing, level, and descending flights of this easterly mass migration are summarized in Table 4. One may assume that climbing flocks often reflect migrants that have recently departed on a new flight step, while descending flocks reflect migrants that are about to land and make a stopover. Table 4 reveals the following features of the easterly migration. Climbing and descending flights were more common at site $\mathrm{O}$, close to the coast, than farther offshore at sites $\mathrm{M}$ and $\mathrm{N}\left(\chi^{2}=24.3, \mathrm{df}=4, p<0.001\right)$. Climbing flights were on average directed more to the north (58\% of the climbing tracks had directions north of due east), with mean track direction $85^{\circ}$, than were descending flights (only $25 \%$ north of due east), with mean track direction $105^{\circ}$. Level flights were intermediate (with $40 \%$ in the northeastern quadrant), with a mean track direction of $97^{\circ}$. Differences between mean directions of climbing, descending, and level flights are statistically significant (Watson-Williams test, $\mathrm{F}_{2,276}=11$, $p<0.001$; cf. Batschelet, 1981). Heading directions did not show the same consistent differences as the track directions. However, track directions are probably of primary relevance because the migrants generally seemed to accomplish compensation for wind drift, i.e., they varied their heading directions in order to maintain their preferred track directions under different wind conditions (Green et al., unpubl. data). Most climbing flights were recorded in the late evening and night (mainly 2000-0100), while descending flights showed a peak in the morning hours (mainly $0500-1100$ ).

Westward Migration: There was a wide geographic overlap in the occurrence of westerly and easterly migration, both in the region of $70^{\circ} \mathrm{N}$ from King William Island and westwards to the Beaufort Sea, and at more northerly 
TABLE 4. Numbers, directions, and timing of climbing, level, and descending flights at sites $\mathrm{M}, \mathrm{N}$, and $\mathrm{O}$. The data refer to migration in easterly directions $\left(0-180^{\circ}\right)$ only. Tracks with vertical speeds more than $0.4 \mathrm{~m} / \mathrm{s}$ and less than $-0.4 \mathrm{~m} / \mathrm{s}$ are classified as climbing and descending flights, respectively, with remaining tracks classified as level flights. Calculation of heading directions is based on the number of tracks given in parentheses (slightly smaller than the total number used to calculate track directions because of missing wind data).

\begin{tabular}{|c|c|c|c|c|c|c|c|c|c|c|c|}
\hline & \multicolumn{4}{|c|}{ Site } & \multicolumn{2}{|c|}{ Track direction } & \multicolumn{2}{|c|}{$\underline{\text { Heading direction }}$} & \multicolumn{3}{|c|}{ Local time } \\
\hline & $\mathrm{M}$ & $\mathrm{N}$ & $\mathrm{O}$ & $\mathrm{M}+\mathrm{N}+\mathrm{O}$ & Mean & $\mathrm{r}$ & Mean & $\mathrm{r}$ & $2000-0400$ & $0400-1200$ & $1200-2000$ \\
\hline Climb & 23 & 5 & 36 & $64(61)$ & $85^{\circ}$ & 0.90 & $117^{\circ}$ & 0.93 & 31 & 23 & 10 \\
\hline Level & 81 & 18 & 49 & $148(140)$ & $97^{\circ}$ & 0.92 & $109^{\circ}$ & 0.92 & 48 & 74 & 26 \\
\hline Descent & 16 & 7 & 44 & $67(64)$ & $105^{\circ}$ & 0.90 & $126^{\circ}$ & 0.92 & 19 & 39 & 9 \\
\hline Total & 120 & 30 & 129 & $279(265)$ & $96^{\circ}$ & 0.90 & $115^{\circ}$ & 0.91 & 98 & 136 & 45 \\
\hline Radar hours & 35.5 & 22 & 33.5 & 91 & & & & & 24.5 & 40.5 & 26 \\
\hline Total tracks per radar hour & 3.4 & 1.4 & 3.9 & 3.1 & & & & & 4.0 & 3.4 & 1.8 \\
\hline
\end{tabular}

latitudes at Banks, Melville, and southern Ellesmere Islands. However, the magnitude of the westerly migration was often at a lower level, and no occasions of mass migration, similar to the huge eastward migration at the Beaufort Sea, were recorded for the westerly movements.

The westward migration in the region of $70^{\circ} \mathrm{N}$ consisted of at least three different types of movement. (1) Migration along the coast of common eiders Somateria mollissima low over the sea surface was recorded at Amundsen Gulf (K), involving both eider males (molt migration) as well as a few flocks of oldsquaws Clangula hyemalis. (2) Another category of low-altitude movements was recorded farther offshore at the same site (K), presumably consisting of long-tailed jaegers Stercorarius longicaudus and occurring at a density of at least $0.02-0.08$ flocks/individuals per $\mathrm{km}^{2}$ over Amundsen Gulf and adjoining waters. The movements mainly took place at $10-100 \mathrm{~m}$ altitude, often far offshore, and they may have been a combination of foraging and migratory flights. Directions were highly scattered, but still there was a significant dominance of westward flights at site K (Fig. 2, Table 2). (3) Westward migration at several hundred meters of altitude on a broad front over pack ice and land, with much low-level fog, was recorded at King William Island $(\mathrm{H})$. Mean height was $591 \mathrm{~m}$, and mean direction was due west, $270^{\circ}(\mathrm{r}=0.89$, $\mathrm{n}=32$; Table 2). Similar movements were sparsely recorded also at the Beaufort Sea sites (M, N, O). Combining the results from these three Beaufort Sea sites, there were 23 tracks of westerly flights $\left(180-360^{\circ}\right)$ with a mean direction of $278^{\circ}(\mathrm{r}=0.81)$ and a mean altitude of $339 \mathrm{~m}$ (range 87-936 m). One of these westerly tracks was identified as a long-tailed jaeger.

At the northernmost latitudes, westward movements occurred to approximately the same extent as eastward migration. Hence, at northern Banks Island (R), there were 16 tracks in the interval $220-300^{\circ}$; at Melville Island (S), 13 tracks in the interval $190-290^{\circ}$; and at southern Ellesmere Island (U), 3 tracks in the interval $237-283^{\circ}$. Of these 32 tracks (at sites R, S, and U), 20 fell in the sector $220-270^{\circ}$ and 10 in the sector $270-300^{\circ}$. The mean altitude was $866 \mathrm{~m}$, and as many as 11 tracks were recorded at altitudes exceeding $1000 \mathrm{~m}$, with the highest at $2830 \mathrm{~m}$. Only 3 of these 32 westerly tracks were below $250 \mathrm{~m}$.
The identity of the westward migration is, with the exception of the eider migration, uncertain. Long-tailed jaegers were suspected to be important in the westerly movements in the region of $70^{\circ} \mathrm{N}$ latitude, both in the lowaltitude movements in Amundsen Gulf and in the westerly flights at King William Island and the Beaufort Sea. This species may also have been involved in the westerly migration at more northerly sites. However, the regular incidence of high-altitude flights may indicate that shorebirds and terns also participated in these movements.

Northward Migration: Northward movements were most pronounced at northern Banks Island (R), where as many as 46 tracks were in the interval $310-50^{\circ}$ (12 above $1000 \mathrm{~m}$, the highest at $1480 \mathrm{~m}$ ), and the overall mean direction was towards due north (Table 2). In addition, northward flights were recorded at southern Banks Island (L; 6 tracks in the sector $7-58^{\circ}$, with birds climbing from the sea and departing across Banks Island) and at Melville Island (S; 9 tracks in the sector $320-30^{\circ}$ ). Northward flights were even occurring as far north as Ellef Ringnes Island (T), as demonstrated by two tracks, towards $4^{\circ}$ and $6^{\circ}$, respectively, at this site.

One of the northward climbing flights at site $\mathrm{L}$ was identified as a flock of three long-tailed jaegers, and we suspect that jaegers were leaving their concentration areas at Amundsen Gulf to exploit other newly ice-free waters farther north. Field observations at sites R, S, and T suggested that red phalaropes and arctic terns Sterna paradisaea were additional candidate species for these movements.

Southward Migration: South was an important migratory direction mainly at Baffin Island. The migration patterns at sites $\mathrm{Y}$ and $\mathrm{Z}$ were very similar, suggesting that the same types of movement were involved. At both sites, there was an indication of a possible bimodality in track directions, with peak directions towards southeast and south (Fig. 2). Combining the data from the two sites (in total 54 tracks), there were 18 tracks in the sector 110 $150^{\circ}$ and 26 tracks in the sector $160-210^{\circ}$. In the first group, air speed exceeded $13 \mathrm{~m} / \mathrm{s}$ in 14 of the 18 cases $(78 \%)$, and mean air speed was $14.9 \mathrm{~m} / \mathrm{s}(\mathrm{SD}=3.6 \mathrm{~m} / \mathrm{s}, \mathrm{n}$ $=18$ ). In the latter group, air speed exceeded $13 \mathrm{~m} / \mathrm{s}$ in only 7 of the 26 cases (27\%), and mean air speed was $12.2 \mathrm{~m} / \mathrm{s}$ 


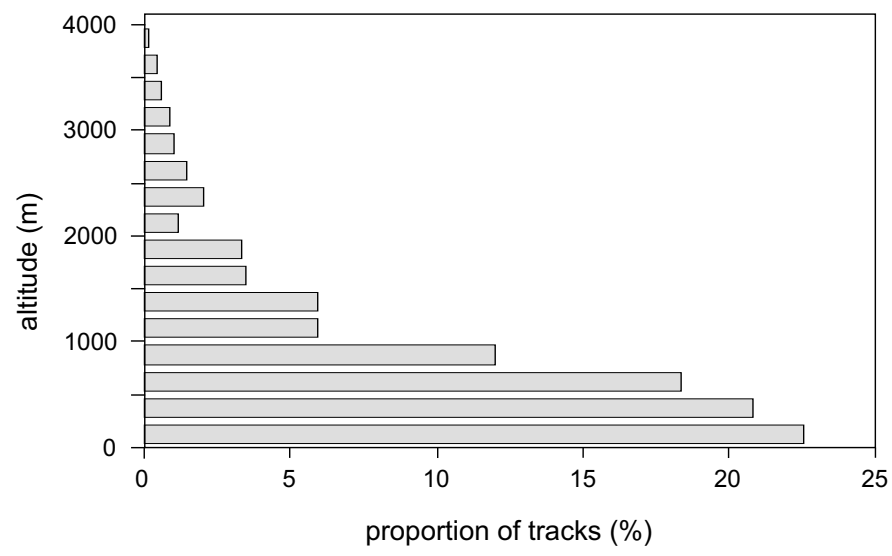

FIG. 4. Distribution of flight altitudes for the total sample of radar tracks $(n=692)$.

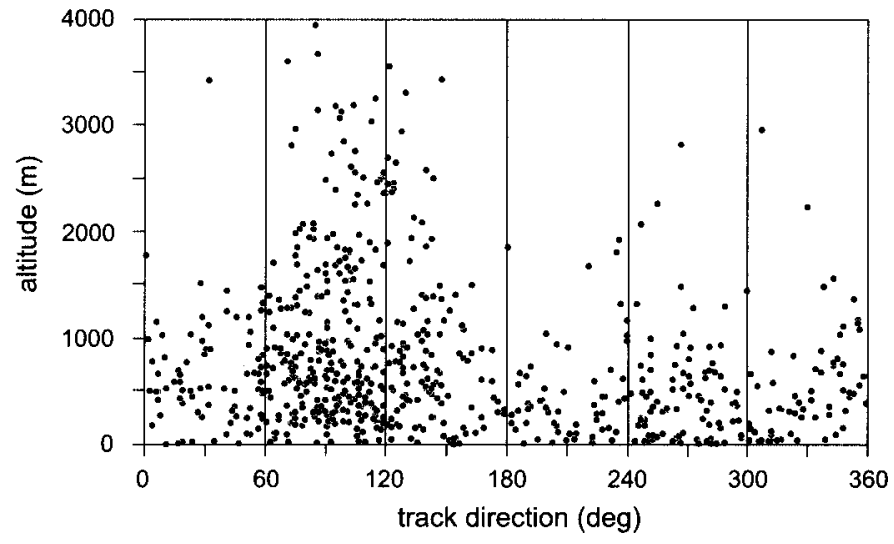

FIG. 5. Altitude in relation to track direction for the total sample of radar tracks $(\mathrm{n}=692)$.

$(\mathrm{SD}=2.6 \mathrm{~m} / \mathrm{s}, \mathrm{n}=26)$. These differences in air speeds between tracks in the two sectors are statistically significant ( $\mathrm{t}$-test, $\mathrm{t}=2.9, p<0.01)$. This indicates that species composition may have differed between the two sectors, with passerines (presumably having on average lower air speeds than most shorebirds) possibly being relatively more common among tracks towards south and southsouthwest. The overall mean direction of 50 southerly $\left(90-270^{\circ}\right)$ tracks at sites $\mathrm{Y}$ and $\mathrm{Z}$ was $168^{\circ}(\mathrm{r}=0.82)$.

\section{Flight Altitudes}

The total distribution of altitudes is shown in Figure 4. The overall mean and median altitudes were 793 and $584 \mathrm{~m}$, respectively. As seen from the figure, $26.2 \%$ of the tracks were at altitudes exceeding $1 \mathrm{~km}$, with $18.6 \%$ in the interval $1-2 \mathrm{~km}, 5.6 \%$ at $2-3 \mathrm{~km}$, and $2 \%$ at $3-4 \mathrm{~km}$. Although high altitudes were sparse, they occurred at several different sites. Tracks with altitudes above $3 \mathrm{~km}$ were recorded at seven of the sites (Table 2). Mean altitudes were in the 500-900 m range at most sites. Exceptions on the low side were sites $\mathrm{K}$ and $\mathrm{L}$, where movements low over the sea dominated. Site N, situated $100 \mathrm{~km}$ north of Herschel Island near the pack ice edge in the Beaufort
Sea, was exceptional in the opposite respect, with a dominance of high-altitude migration (74\% of the tracks above $1000 \mathrm{~m}$ ) and a mean altitude as high as $1926 \mathrm{~m}$ (Table 2). The highest altitude observed during the expedition, $3948 \mathrm{~m}$, was recorded at this site. Mean altitude was also unusually high at site $\mathrm{U}$ on southern Ellesmere Island, but the number of tracks was small.

Altitudes are plotted in relation to track direction for the total data set in Figure 5. High altitudes $(>1.5 \mathrm{~km})$ were mainly associated with eastward migration in the sector $70-140^{\circ}$. In addition, there was an indication of recurrent high altitudes for westward migration in the sector 230 $270^{\circ}$. In contrast, altitudes exceeding $1.5 \mathrm{~km}$ were notably scarce among the northerly and southerly movements.

\section{Flight Speeds}

Tracks with vertical speeds between -0.4 and $0.4 \mathrm{~m} / \mathrm{s}$ were classified as level flights. Such flights accounted for $56 \%$ of all tracks $(n=692)$, while there were $23 \%$ descending and $20 \%$ ascending flights. The overall mean vertical speed was close to zero, $-0.06 \mathrm{~m} / \mathrm{s}$ (Table 2). About half of the descending flights ( $12 \%$ of all tracks) were steep descents with vertical speeds faster than $-0.8 \mathrm{~m} / \mathrm{s}$, and in $3 \%$ of the cases the birds even descended, or dived, at vertical speeds faster than $-1.6 \mathrm{~m} / \mathrm{s}$. The proportion of steep climbs (with vertical speeds exceeding $0.8 \mathrm{~m} / \mathrm{s}$ ) was $7.5 \%$, while climbs steeper than $1.6 \mathrm{~m} / \mathrm{s}$ were almost nonexistent (only 3 cases, with maximum vertical speed of $2.4 \mathrm{~m} / \mathrm{s}$ ).

The total distributions of ground, air, and wind speeds are illustrated in Figure 6, and the corresponding means and standard deviations are given in Table 2. Ground speed was on average only slightly faster than the mean air speed, and the scatter was considerably larger for ground speeds than for air speeds. While $89 \%$ of all air speeds fell in the range $8-18 \mathrm{~m} / \mathrm{s}$ and only $9 \%$ exceeded $18 \mathrm{~m} / \mathrm{s}$, the corresponding proportions of ground speeds were $64 \%$ and $27 \%$, respectively. Furthermore, in $9 \%$ of the cases, the birds were flying into such unfavorable winds that their ground speed was reduced below $8 \mathrm{~m} / \mathrm{s}$. Wind speeds were mostly in the range $2-12 \mathrm{~m} / \mathrm{s}$, with an overall mean of $6.7 \mathrm{~m} / \mathrm{s}$ (Fig. 6, Table 2).

Migratory birds are expected to prefer following winds for their flights, since this will give them a ground speed that is faster than their air speed, reducing flying time as well as energy expenditure per distance covered. However, as seen from Figure 7, there was only a rather slight overweight in favor of cases where the birds gained in speed from the wind (ground speed exceeding air speed), making up 55\% of the total sample of radar tracks, while the wind caused a loss in speed in the remaining proportion of tracks. The wind effect (ground speed minus air speed) was rather small (between -4 and $4 \mathrm{~m} / \mathrm{s}$ ) in $45 \%$ of all cases, but in $11 \%$ of the cases the birds gained more than $8 \mathrm{~m} / \mathrm{s}$ in speed from the wind, and in $2.5 \%$ of the cases, they lost more than $8 \mathrm{~m} / \mathrm{s}$ in speed (Fig. 7). 

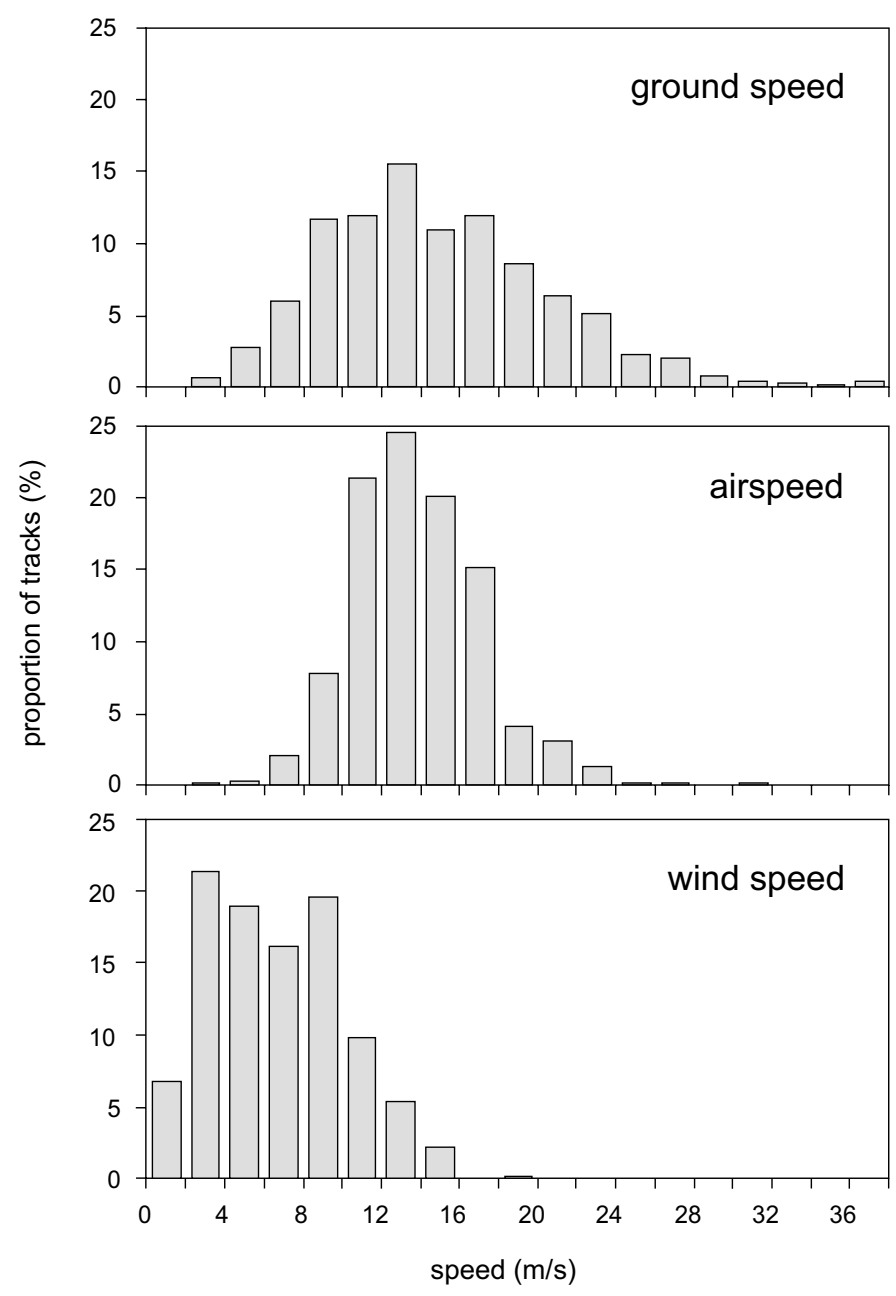

FIG. 6. Distribution of ground speed $(n=692)$, air speed $(n=644)$, and wind speed $(n=644)$ for the total sample of radar tracks.

The wind effect differed between sites, as can be seen from Table 2 by comparing mean ground and air speeds at the respective sites. Hence, the largest gains in speed obtained from the wind were recorded for the migrants at sites J (eastward migration) and Z (southward migration), where the following winds were strong (mean wind speed exceeded $10 \mathrm{~m} / \mathrm{s}$ ): average ground speed exceeded $20 \mathrm{~m} / \mathrm{s}$ at both these sites. For the eastward mass migration at the Beaufort Sea, the average wind effect was moderately positive at sites $\mathrm{M}$ and $\mathrm{N}$, but negative at site $\mathrm{O}$. The wind effect is plotted in relation to track direction in Figure 8. This shows that the wind effect was very variable and not consistently positive or negative for any directional cohort. The proportion of tracks with a positive wind effect was comparatively large in the sector $60-90^{\circ}$, while negative wind effects were more common in the sector 100 $130^{\circ}$. The northerly movements were frequently associated with unfavorable winds that reduced the ground speed to levels below the air speed (Fig. 8).

Investigating the wind effect in relation to altitude (Fig. 9) reveals that there was a distinct dominance of positive wind effects at the highest altitudes, above $2 \mathrm{~km}$. However, the cases where the birds gained most (more

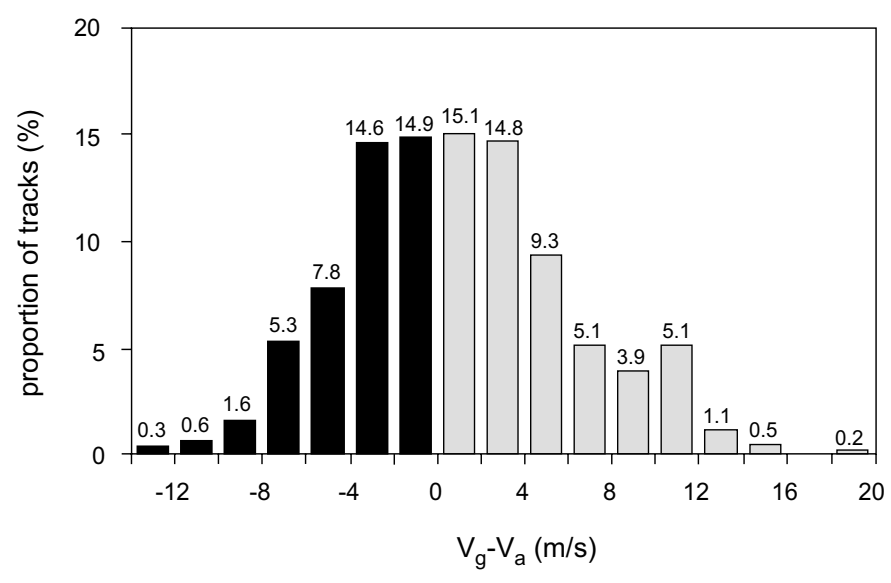

FIG. 7. Distribution of wind effect (ground speed minus air speed) for the 644 radar tracks for which both ground speed and air speed were available. The diagram and numbers show the percentage distribution.

than $10 \mathrm{~m} / \mathrm{s}$ ) in speed from the wind were at lower levels, often at only a few hundred meters of altitude.

\section{DISCUSSION}

\section{Migration Patterns}

Our results demonstrate that the migration patterns in High Arctic Canada are much more complex than those along the Northeast Passage (Alerstam and Gudmundsson, 1999a). At the Northeast Passage, there is a major and clear-cut migratory divide at the most northerly peninsula (Taymyr) of the Eurasian continent (about longitude 100$110^{\circ} \mathrm{E}$ ), with eastward migration strongly dominating to the east of this divide and westward migration to the west of it (Alerstam and Gudmundsson, 1999a). In contrast, eastward movements are important throughout the whole of Arctic North America, but there are also sites and occasions with significant migration towards the west, north, and south (Table 2, Fig. 2). The overall mean direction for all data pooled was towards the east $\left(100^{\circ}\right)$, but the scatter into all different compass directions was very large (Table 2).

The field observations during our expedition, in combination with identified radar targets and information from the literature (see below), strongly suggest that the overwhelming majority of shorebirds (except the red phalarope; cf. below) migrate in easterly directions throughout the study region, or towards the south, as at Baffin Island. In contrast, jaegers, terns, gulls, ducks, and red phalaropes migrate in both easterly and westerly directions (Johnson and Herter, 1989, 1990), and for these birds there are presumably migratory divides in the study area between populations destined for winter quarters in the Pacific and Atlantic regions, respectively. It is very likely that birds from this latter group were responsible for the northward migration recorded at some sites. 


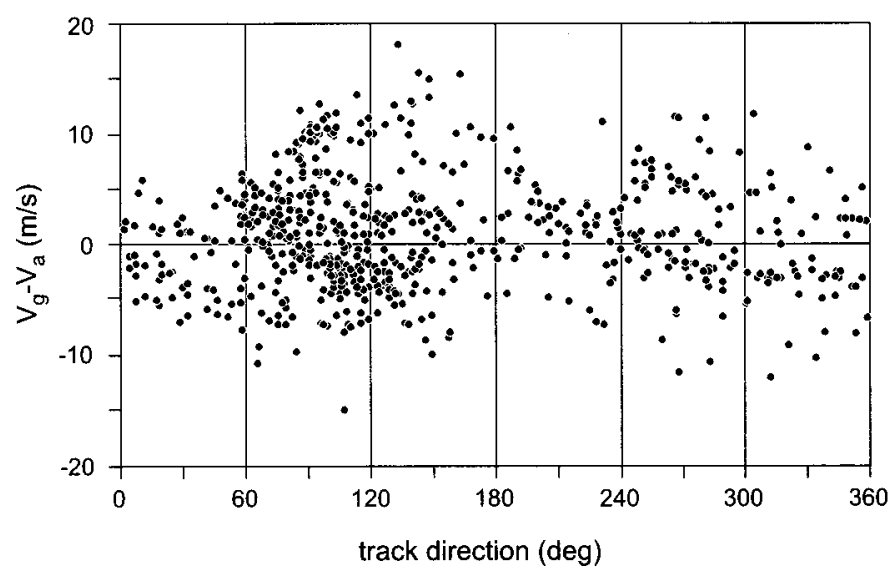

FIG. 8. Wind effect (ground speed minus air speed) in relation to track direction $(\mathrm{n}=644)$.

\section{Eastward and Southward Migration}

The eastward and southward movements recorded during the expedition may reflect at least four different main groups of migratory birds in Arctic North America (cf. Morrison, 1984): (1) Shorebirds migrating via Greenland and Iceland and wintering in Western Europe. (2) Shorebirds migrating via the east coast of North America towards South American winter quarters. Many of these migrants make a transoceanic flight across the western Atlantic Ocean (Williams and Williams, 1978, 1990; Stoddard et al., 1983; Morrison, 1984). Large numbers depart towards the southeast across the Atlantic from a wide region at Nova Scotia (Richardson, 1979), where there are shorebird stopover sites of key importance (Morrison and Harrington, 1979; Morrison et al., 1995). Such departures also take place from Labrador and the Gulf of St. Lawrence farther to the north, as well as from important stopover sites farther to the south along the Atlantic coast of the United States (McNeil and Burton, 1977; Morrison, 1984). (3) Shorebirds migrating through the interior of North America, e.g., via the Mackenzie and Missouri river systems, towards the Gulf of Mexico and farther towards Central and South American winter quarters. (4) Seabirds (jaegers, terns) and red phalaropes migrating via Davis Strait or the waters off Labrador, Newfoundland, and Nova Scotia across the Atlantic Ocean towards winter waters in the East Atlantic Ocean off Africa or, in the case of the arctic tern, farther towards the Antarctic pack ice.

The shorebird migration system that encompasses routes via the east coast of North America is of huge dimensions, involving millions of birds and many of the key species in our study area (see Morrison, 1984 for a comprehensive review of this migration system), such as white-rumped sandpiper (Morrison, 1984; Harrington et al., 1991; Parmelee, 1992; Harrington, 1999), semipalmated sandpiper (Morrison, 1984; Gratto-Trevor, 1992), American golden-plover (Johnson and Connors, 1996; Byrkjedal and Thompson, 1998), red knot (Morrison, 1984; Harrington,

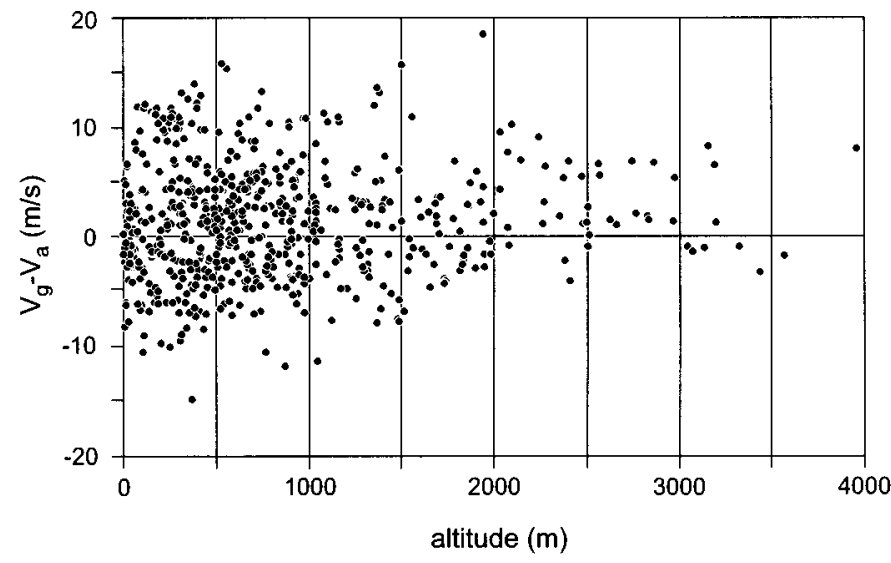

FIG. 9. Wind effect (ground speed minus air speed) in relation to altitude $(\mathrm{n}=644)$.

1996), pectoral sandpiper (Holmes and Pitelka, 1998), black-bellied plover (Paulson, 1995; Byrkjedal and Thompson, 1998), red-necked phalarope (with oceanic winter quarters; Harrison, 1985), and buff-breasted sandpiper (Lanctot and Laredo, 1994). Recent estimates of the population sizes of North American shorebird species migrating along the eastern, interior, and Pacific flyways are given by Morrison et al. (2001). The winter distributions in South America of many of these species have been determined by aerial surveys by Morrison and Ross (1989). Haig et al. (1997) used molecular methods to study the population structure of some shorebird species. Their results support an eastward migration across North America.

The shortest route between two points on the Earth's surface is along an orthodrome (a great circle, involving a changing geographic course) and not along a path of constant geographic course (a loxodrome or rhumb line). The shorter distance means that birds will save both time and energy for their migratory journey by following orthodromes rather than loxodromes, and this effect is most pronounced for movements in east-west directions at high latitudes.

The track directions of eastward and southward migration at the different sites are summarized in relation to the calculated courses towards Nova Scotia along orthodromes (the departure course is given) and loxodromes in Table 5, which also gives the distances from the different sites to Nova Scotia. Main and secondary track directions as recorded by radar at different sites are also schematically indicated in Figure 10 on two different map projections (Mercator and gnomonic). Loxodromes appear as straight lines on the Mercator projection, while orthodromes appear as straight lines on the gnomonic projection (Gudmundsson and Alerstam, 1998b).

A common feature at almost all sites is that the recorded tracks to a large extent were directed to the north of the loxodrome courses towards Nova Scotia (except at sites Y and $\mathrm{Z}$, where differences between observed track directions and calculated courses along loxodromes as well as orthodromes were minor) (Table 5). In fact, if the birds 

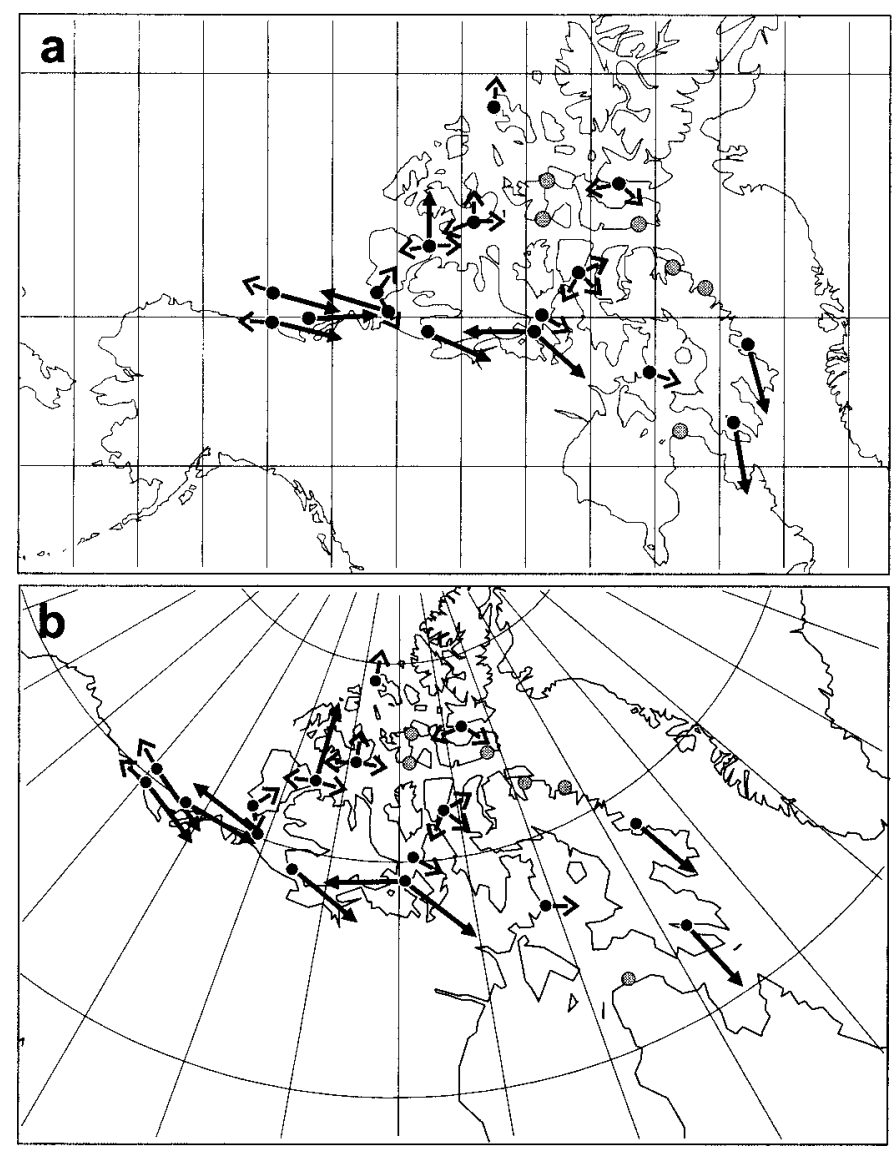

FIG. 10. Flight directions at different sites plotted on two different map projections, (a) Mercator and (b) gnomonic. Long arrows show mean directions of major movements, while short arrows show directions indicated by a smaller number of radar tracks (cf. Tables 2 and 4, Fig. 2 and text). The gnomonic projection is not true to angles, but the distortions are negligible at the high latitudes of the study area.

were to follow loxodromes, maintaining fixed geographic courses, the vast majority would migrate towards Greenland (Fig. 10). Hence, it is reasonable to assume that they change their orientation to more southeasterly courses along the routes. In a separate paper (Alerstam et al., 2001), we have analyzed the eastward migration at the main sites $(\mathrm{H}, \mathrm{J}, \mathrm{M}, \mathrm{N}, \mathrm{O})$ in relation to predicted routes, assuming that the birds follow either geographic loxodromes (orienting by time-independent celestial rotation cues), magnetic loxodromes (orienting by a magnetic compass), or time-dependent sun compass routes. Sun compass routes are close approximations of orthodromes at high latitudes, showing gradually changing geographic courses as the birds travel across longitudes and their internal clocks get out of phase with local time (Alerstam and Pettersson, 1991). It was evident from this analysis that the observed track directions could not be reconciled with orientation along either geographic or magnetic loxodromes, but did support migration along orthodromelike sun compass routes (Alerstam et al., 2001; see also Alerstam and Gudmundsson, 1999b).

As seen from Table 5, there is good agreement between the recorded track directions and great circle courses towards Nova Scotia for sites G, H, J, and M. For sites N and $\mathrm{O}$, the mean track direction falls to the south of the great circle course towards Nova Scotia, indicating that the majority of migrants recorded at these sites may travel towards the Atlantic coast south of Nova Scotia. This is consistent with the existence of considerable variation in the possible headings of birds using stopover sites scattered along an extensive part of the east coast of North America, as demonstrated (for example) by banding studies of semipalmated sandpipers (Gratto-Trevor and Dickson, 1994). These studies also show that birds using easterly coastal flyways in the fall return by more westerly central routes in spring.

Great circle courses slightly (about $10^{\circ}$ ) north of those towards Nova Scotia point towards the Gulf of St. Lawrence and Labrador, which are also important regions of passage for the shorebirds-not least the white-rumped sandpipers, which seem to make the longest transoceanic flights to South America (Morrison, 1984). At some sites (e.g., C, D, R, and S), track directions were even farther to the north than this. Tracks about $100-110^{\circ}$ at sites $\mathrm{C}$ and $\mathrm{D}$, and about $80-90^{\circ}$ at sites $\mathrm{R}$ and $\mathrm{S}$, would be consistent with orthodromic migration routes extending via Davis Strait towards oceanic areas off the coast of West Africa. It seems probable that tracks with courses pointing towards areas north of Labrador primarily reflect seabirds (jaegers, terns, Sabine's gulls Xema sabini), as well as red phalaropes migrating into the Atlantic Ocean via the region at Davis Strait. Possibly such seabird migration may also account for some of the southeasterly tracks (110$140^{\circ}$ ) at the Baffin sites $\mathrm{Y}$ and $\mathrm{Z}$ (the great circle course from here towards West Africa is about $125^{\circ}$ ), although the majority of migrants at these sites were traveling on southerly courses towards the east coast of North America.

Track directions about $60-70^{\circ}$ at sites $\mathrm{C}, \mathrm{D}, \mathrm{R}$, and $\mathrm{S}$ are expected for great circle routes across Greenland towards Iceland. However, it seems highly speculative to assume that the few east-northeasterly tracks at these sites were destined for Iceland and western Europe (they may, for example, represent less wide-ranging movements within the Arctic region). One would expect migration towards these destinations to be most likely at sites $\mathrm{U}$ and $\mathrm{T}$, which are close to the breeding ranges of those populations of red knot, ruddy turnstone, and ringed plover Charadrius hiaticula that are known to migrate towards Iceland and western Europe (Morrison, 1984). However, the few tracks recorded at these sites were more in accordance with routes towards the American side of the Atlantic (Table 5).

An important finding concerning the eastward migration is that shorebirds migrating by transoceanic flights from the east coast of North America towards South America are recruited to such a large extent from regions as far west as the Beaufort Sea and even farther west. The distances from the Beaufort sites (M, N, O) to Nova Scotia are about $5000 \mathrm{~km}$ (Table 5), with orthodromes $5 \%$ shorter than geographic loxodromes. The eastward shorebird migration has also been recorded by radar at the north coast 
TABLE 5. Observed track directions of eastward and southward migration in relation to the orthodrome and loxodrome courses towards Nova Scotia from different sites. The distances (along the orthodromes) to Nova Scotia $\left(45^{\circ} \mathrm{N}, 63^{\circ} \mathrm{W}\right)$ are also given. The orthodrome courses refer to departure courses from the sites. Mean directions refer to tracks in the interval $0-180^{\circ}$ for all sites except $\mathrm{Y}$ and $\mathrm{Z}$, where means are based on tracks in the sector $90-270^{\circ}$ (cf. Fig. 2). A mean geographic position of $70^{\circ} \mathrm{N}, 136^{\circ} \mathrm{W}$ is used for the combined data of sites $\mathrm{M}, \mathrm{N}$, and $\mathrm{O}$, and a mean position of $66^{\circ} \mathrm{N}, 67^{\circ} \mathrm{W}$, for the data from sites $\mathrm{Y}$ and $\mathrm{Z}$. Mean vector length $\mathrm{r}$ reflects the degree of scatter of direction (Batschelet, 1981).

\begin{tabular}{|c|c|c|c|c|}
\hline \multirow[t]{2}{*}{ Site } & \multicolumn{2}{|c|}{ Course towards Nova Scotia } & \multirow{2}{*}{$\begin{array}{c}\text { Distance to } \\
\text { Nova Scotia }(\mathrm{km})\end{array}$} & \multirow[t]{2}{*}{ Observed track directions of eastward and southward migration (degrees) } \\
\hline & $\begin{array}{c}\text { Orthodrome } \\
\text { (degrees) }\end{array}$ & $\begin{array}{c}\text { Loxodrome } \\
\text { (degrees) }\end{array}$ & & \\
\hline $\mathrm{C}$ & 148 & 157 & 2740 & 4 tracks: $32,105,108,111$ \\
\hline D & 137 & 152 & 3444 & 6 tracks: $46,62,82,101,147,159$ \\
\hline G & 128 & 145 & 3408 & 4 tracks: $118,119,121,128$ \\
\hline $\mathrm{H}$ & 124 & 143 & 3376 & 18 tracks: mean direction $132(\mathrm{r}=0.90)$ \\
\hline $\mathrm{J}$ & 106 & 132 & 4031 & 21 tracks: mean direction $102(\mathrm{r}=0.79)$ \\
\hline M & 88 & 125 & 4863 & 120 tracks: mean direction $88(\mathrm{r}=0.94)$ \\
\hline $\mathrm{N}$ & 84 & 124 & 5126 & 30 tracks: mean direction $106(r=0.95)$ \\
\hline $\mathrm{O}$ & 82 & 122 & 5161 & 129 tracks: mean direction $102(r=0.87)$ \\
\hline $\mathrm{M}, \mathrm{N}, \mathrm{O}$ & 86 & 124 & 4989 & 279 tracks: mean direction $96(r=0.90)$ \\
\hline $\mathrm{R}$ & 111 & 139 & 4212 & 23 tracks $30-180$, with 9 tracks $30-60$ and 6 tracks $80-110$ \\
\hline $\mathrm{S}$ & 121 & 145 & 4035 & 10 tracks $30-180$, with 8 tracks $59-127$ \\
\hline $\mathrm{T}$ & 129 & 153 & 4224 & 1 track: 143 \\
\hline $\mathrm{U}$ & 147 & 161 & 3678 & 4 tracks: $129,134,139,148$ \\
\hline $\mathrm{Y}$ & 174 & 176 & 2630 & 20 tracks: mean direction $161(\mathrm{r}=0.80)$ \\
\hline $\mathrm{Z}$ & 168 & 170 & 2107 & 30 tracks: mean direction $172(r=0.83)$ \\
\hline $\mathrm{Y}, \mathrm{Z}$ & 172 & 174 & 2346 & 50 tracks: mean direction $168(\mathrm{r}=0.82)$ \\
\hline
\end{tabular}

of Alaska (Flock, 1973), and there are links with migration all the way from Siberia (Alerstam and Gudmundsson, 1999a). Flock (1973) described eastward migration (mostly towards $90-100^{\circ}$, according to a radar screen photo from 2 August) on a broad front during July and August at three radar stations along the north coast of Alaska $\left(143-157^{\circ} \mathrm{W}\right)$. The birds could not be discovered visually, and it was estimated that some of the migrants were at altitudes near $3000 \mathrm{~m}$. Flock (1973) concluded that, although the identity of these migrants could not be ascertained, they were likely shorebirds that would later head south along the valley of the Mackenzie River. A study of visible migration at Nunaluk Spit, Yukon Territory (only a few kilometers from our westernmost site, reached on 3-5 August, near Herschel Island; see site $\mathrm{O}$ in the Appendix), in summer and autumn 1987 revealed a peak of shorebird migration during the first 10 days of August (Ealey et al., 1988). Of a total 9350 migrant birds counted during 1-10 August, shorebirds accounted for $96 \%$. A single species, the rednecked phalarope, accounted for $86 \%$ of the observations, and the migration directions of those birds were predominantly towards east (Ealey et al., 1988). Another study in the same region in autumn 1972 found largely easterly movements of red-necked phalaropes (Salter et al., 1980).

However, our radar observations demonstrate that many of the above-mentioned migrants do not head south at the Mackenzie River delta, but continue on easterly courses. We conclude that there is a large-scale autumn migration system of shorebirds-extending all the way from Alaska (and partly also from Siberia, cf. Alerstam and Gudmundsson, 1999a, b) across the whole of Arctic North America-that moves along routes similar to great circles towards the east coast of North America (and farther, towards South American winter quarters). Visual observations of important eastward shorebird migration in July, August, and September at the Alaska and Yukon Beaufort Sea coast, involving species such as the American goldenplover, semipalmated sandpiper, long-billed dowitcher Limnodromus scolopaceus, and red-necked phalarope, lend further support to this conclusion (Johnson and Herter, 1989).

A few of the shorebird species breeding in the study region, such as Baird's sandpiper (Jehl, 1979) and stilt sandpiper Micropalama himantopus (Klima and Jehl, 1998), are known to migrate primarily on southward or southeastward courses through the interior of North America. Such movements were apparently not abundant enough to be clearly discernible in our radar data, but they may have contributed to the southerly fringe of radar tracks at sites H, J, and O, for example (cf. Fig. 2).

\section{Westward and Northward Movements}

The radar and visual studies by Richardson and Johnson (1981) of the spring migration of birds at the Yukon and Alaskan coast of the Beaufort Sea showed that large numbers of ducks, loons, jaegers, gulls, terns, and red phalaropes arrive from the west to their High Arctic breeding sites. This is in striking contrast to the shorebirds, which seemed to be responsible for much of the westward spring migration as detected by radar in this region (Richardson and Johnson, 1981). One would assume that the former category of eastbound migrants in spring return by westward postbreeding migration towards winter quarters in the Pacific region. This assumption is supported by the observations of westbound migration in June of 
nonbreeding pomarine jaegers, Stercorarius pomarinus, leaving their breeding range shortly after their spring arrival from the west (Richardson and Johnson, 1981); by the westward molt migration in summer of sea ducks like common eider and oldsquaw (Johnson and Richardson, 1982); and by visual observations of westbound autumn migration of this category of birds at Point Barrow and other places at the Beaufort Sea (Johnson and Herter, 1989).

Flock (1973) described important westward migration during summer at radar stations along the north coast of Alaska, attributing most of the radar echoes to flocks of common eiders. However, part of the migration recorded by the radar took place on a broad front, with some radar echoes passing over the tundra as much as $70 \mathrm{~km}$ south of the coastline. Flock (1973) suspected eider migration also for these movements, but he considered the definite identity as unresolved for lack of visual observations. During peaks of similar broad-front migration towards the east in spring, as recorded at the same radar stations, few migrating birds were seen, but "jaegers, flying to the east a few at a time, were the most common birds actually seen flying purposely in a given direction" (Flock, 1973:265). One may suspect that jaegers were also important in the broad-front westward postbreeding migration during the summer.

Westward migration of male common eiders, including also a few flocks of oldsquaws, was recorded in this study at site $\mathrm{K}$, along the southern coast of Amundsen Gulf. This is in agreement with earlier visual records of conspicuous westward migration of male common eiders in mid to late July at Cape Bathurst, which is situated about $250 \mathrm{~km}$ to the west of site K (Johnson and Richardson, 1982). The distribution and migration of eider populations in this region are described in Dickson (1997). Apart from these movements, there were probably few if any ducks in the westward and northward migrations recorded during our expedition, because the air speeds of the migrants tracked by radar were generally lower than expected for ducks.

Considering the fact that our observations refer to the early part of autumn migration, in July and August, the most likely birds to be involved in the westbound and northbound movements are jaegers, arctic terns, and red phalaropes, which have their main migration period during these months (Johnson and Herter, 1989). In addition, some species of gull, like Sabine's and Ross's gulls Rhodostethia rosea, probably belonged to this group of migrants. Presumably because of the low lemming numbers during the study year, most pomarine jaegers seemed already to have left the study region before the start of our expedition (Kjellén, 2000). However, long-tailed jaegers were regularly encountered, and this species accounted for $77 \%$ of the observed jaegers during the first leg of the expedition (with 19\% parasitic jaeger Stercorarius parasiticus and 4\% pomarine jaeger; Kjellén, 2000). Hence, the long-tailed jaeger probably was the dominating jaeger species in the westbound and northbound migratory movements during the expedition, although both pomarine and parasitic jaegers were involved as well, as indicated by the observations in the waters off Melville Island.

We can distinguish at least four components in the westward and northward migratory movements (Fig. 10) in addition to the common eider migration mentioned above: (1) The westward passage at King William Island (site $\mathrm{H}$ ) on $20-22 \mathrm{July}$, with mean direction $270^{\circ}$ and mean altitude about $600 \mathrm{~m}$. One possibility is that many of these migrants were mainly long-tailed jaegers on their way towards the Amundsen Gulf region. (2) Amundsen Gulf, with its newly ice-free waters, was a concentration area for long-tailed jaegers. The jaegers were recorded in lowaltitude flights, mostly $20-100 \mathrm{~m}$ above the sea surface, at sites $\mathrm{K}$ and L. (3) Northward migration was recorded at Banks Island (L, R), Melville Island (S), and even Ellef Ringnes Island $(\mathrm{T})$. One of these tracks at Banks Island was identified as a flock of three long-tailed jaegers. The ice in M'Clure Strait, in Viscount Melville Sound and surrounding waters at Queen Elizabeth Islands, and along the eastern Beaufort seaboard had just broken up, presumably offering pelagic foraging opportunities for the birds. The observations at southern Banks Island indicated that long-tailed jaegers migrated towards these northerly waters, and observations at sites $\mathrm{R}$ and $\mathrm{S}$ and surrounding waters indicated that arctic terns, red phalaropes, pomarine and parasitic jaegers, and Sabine's and Ross's gulls were also among the birds exploiting these opportunities. (4) Westbound movements at the southeastern Beaufort Sea $(\mathrm{M}, \mathrm{N}, \mathrm{O})$, as well as farther north at sites $\mathrm{R}$ and $\mathrm{S}$, may reflect the migratory exodus of the jaegers, terns, and phalaropes across the Beaufort Sea towards Alaska and the Bering Strait region, and farther into the Pacific Ocean.

We conclude that jaegers, arctic terns, and red phalaropes were the species mainly responsible for the westward and northward migration. After exploiting pelagic food resources in waters where the ice had recently broken up, such as Amundsen Gulf for the long-tailed jaegers and waters farther to the north for all species, they departed from the study area by westbound migration across the Beaufort Sea (cf. Johnson and Herter, 1989).

Salomonsen (1967) suggested that the migratory divide between populations of arctic terns migrating towards Pacific and Atlantic waters was in Alaska. But the studies by Richardson and Johnson (1981) showed that this divide must be farther to the east, in the Canadian Arctic, and demonstrated that this applies not only to the arctic tern, but also to the jaegers and red phalarope. Our observations of important westbound migration from such an easterly longitude as $99^{\circ} \mathrm{W}$ at King William Island indicate that seabirds from Pacific winter quarters may have a very extensive breeding distribution in Arctic Canada. On the other hand, one should remember that eastbound and westbound migrations were about equally common at certain sites (e.g., R and S). Even if shorebirds were responsible for some of the eastward movements at these sites, one cannot exclude that some jaegers, terns, and 
phalaropes were also involved. This would indicate a possible overlap in the postbreeding distribution within the Canadian Arctic of birds from the Atlantic and Pacific migratory populations of these species, making it difficult to define a distinct line of migratory divide.

\section{Flight Altitudes and Speeds}

Altitudes and speeds of the tundra birds migrating in the Canadian Arctic during July and August, as recorded in this study, may be compared with the corresponding data for tundra migrants in Siberia (Alerstam and Gudmundsson, 1999a) and for shorebirds departing in autumn (AugustOctober) from Nova Scotia and New Brunswick towards the southeast, across the Atlantic Ocean (Richardson, 1979).

The altitude distribution of the migrations that we recorded in the Canadian Arctic was generally at lower levels than that of the migration in Siberia, which in turn was somewhat lower than the high-altitude migration at Nova Scotia. The mean (median) migration altitudes were 790 (580) $\mathrm{m}$ in this study, 1330 (990) $\mathrm{m}$ at the Northeast passage (Alerstam and Gudmundsson, 1999a), and 2000 (1700) $\mathrm{m}$ in Nova Scotia (Richardson, 1979), and the top heights were $3.95,4.80$, and $6.65 \mathrm{~km}$, respectively. The proportion of migration recorded above $1000 \mathrm{~m}$ altitude was $27 \%$ in this study (30\% if the low-altitude movements over the sea at sites $\mathrm{K}$ and $\mathrm{L}$ are excluded), $50 \%$ along the Northeast Passage, and $75 \%$ at Nova Scotia.

Why did bird migration take place at lower altitudes in the Canadian Arctic compared with other regions? Two possible reasons are that (1) the flight steps were not so long at the Northwest Passage as over the Arctic Ocean off Siberia and across the Atlantic Ocean from Nova Scotia, and (2) winds were less favorable in the Canadian Arctic and thus failed to promote high-altitude flights to the same degree as in the other two cases.

Most sites in this study were situated only a few kilometers from the nearest shore, and the birds were often traveling over a mosaic of islands, peninsulas, gulfs, and sounds, where potential stopover sites in coastal areas are within reach. In contrast, the migration at the Northeast Passage was mainly recorded at sites $10-90 \mathrm{~km}$ off the nearest tundra shores, and many birds had apparently departed on long-distance flights across the pack ice of the Arctic Ocean (Alerstam and Gudmundsson, 1999a). Some of these flights probably extended over at least 1500 $2500 \mathrm{~km}$ from Siberia towards the coast of Arctic North America (Alerstam and Gudmundsson, 1999b). The birds at Nova Scotia were departing on 3000-5000 km nonstop transoceanic flights towards the Caribbean region and South America (Williams and Williams, 1978, 1990; Richardson, 1979; Morrison, 1984).

In the present study, there was only one site $(\mathrm{N})$ where the mean altitude approached $2000 \mathrm{~m}$, which was a common mean altitude at sites off the coast of East Siberia (Alerstam and Gudmundsson, 1999a). As this site was situated $100 \mathrm{~km}$ north of the coast in the Beaufort Sea, it reflected migration well to the north of the mainland tundra, which presumably involved a high proportion of long-distance flights. It seems quite likely that many of the migrants at this site were in fact arriving from Siberia, having flown across the Arctic Ocean along orthodromic routes, as suggested by Alerstam and Gudmundsson (1999a, b).

The proportion of climbing and descending flights (compared with level flights) was larger in this study than along the Northeast Passage in Siberia. At the Northeast Passage, $75 \%$ of all tracks were approximately level (with vertical speed between -0.4 and $+0.4 \mathrm{~m} / \mathrm{s}$ ), $17 \%$ were climbs, and $8 \%$ were descents (Alerstam and Gudmundsson, 1999a). The corresponding figures in this study $(56 \%, 20 \%$, and $23 \%$, respectively) indicate that a larger proportion of the migrants was starting from or landing at stopover sites in the Canadian Arctic than at the Northeast Passage.

The flight speeds revealed that the migrants in this study gained assistance from the winds to only a small degree, in strong contrast to the situation at the Northeast Passage and at Nova Scotia. The overall mean air speeds of the migrants in this study $(13.8 \pm 3.4 \mathrm{~m} / \mathrm{s} ; \mathrm{n}=644)$ and at the Northeast Passage $(13.8 \pm 3.0 \mathrm{~m} / \mathrm{s} ; \mathrm{n}=903)$ were exactly the same, reflecting the similar composition of the two groups (mainly shorebirds, but with jaegers and terns also involved in the movements). However, the average ground speed at the Northeast Passage $(18.4 \pm 5.5 \mathrm{~m} / \mathrm{s}$; $\mathrm{n}=1087)$ was clearly faster than in this study $(14.9 \pm 5.8$ $\mathrm{m} / \mathrm{s} ; \mathrm{n}=692$ ). While as many as $36 \%$ of all migrants were traveling with ground speeds exceeding $20 \mathrm{~m} / \mathrm{s}$ at the Northeast Passage, only $18 \%$ were traveling this fast in the present study. The shorebirds were assisted by following winds to an even higher degree at Nova Scotia, as indicated by the high mean ground speed of $20.6 \pm 4.7 \mathrm{~m} / \mathrm{s}$ reported by Richardson (1979). The relatively poor wind assistance in the Canadian Arctic is also evident when considering the wind effect in terms of the difference between ground and air speeds for individual tracks (Fig. 7).

The data for both the Northeast and the Northwest Passages are from only one migration season each, and one must be aware that wind conditions may differ considerably from year to year. Still, the known differences in long-term patterns of barometric pressure and wind of the different Arctic regions seem to indicate that eastbound migrants in Siberia can normally exploit favorable tailwinds associated with low-pressure systems to a higher degree than can migrants in the Canadian Arctic or westbound migrants in northern Europe and Siberia (Lamb, 1972). Transoceanic departures at Nova Scotia mainly take place with strong westerly or northwesterly winds behind cold fronts, which are associated with the regular autumn passages of low-pressure systems in this area (Richardson, 1979).

Although the migrants travel more often at lower altitudes and with less wind assistance, and perhaps sometimes also 
by shorter flight steps, in the region of the Northwest Passage in comparison with other regions, the overall speed of migration to the major staging sites at the Atlantic coast of North America seems to be high (Morrison, 1984). This suggests that the birds have a high degree of flexibility in their fundamental flight and fueling behavior, to maintain a high level of migratory performance under different environmental conditions. Further analyses of differences in migratory strategies between Arctic species, between adults and juveniles, and between different regions comprise a fascinating task for the future.

\section{ACKNOWLEDGEMENTS}

We thank the Swedish Polar Research Secretariat for organizing the expedition and the expedition leader Anders Karlqvist, the Canadian Coast Guard, and the crew of Louis S. St-Laurent for all the help and support that we received for our project. We are greatly indebted to meteorologist Bertil Larsson for invaluable support during all phases of the project (before, after, and throughout the expedition), for arranging and maintaining the radar and other instruments, and for developing efficient computer handling of the radar data. We also thank C.-G. Carlsson and U. Olsson at Aerotech Telub for installing and adapting the radar. We are grateful to expedition members who reported bird observations from the ship and field camps: Noél Holmgren, Göran Högstedt, Nils Kjellén, Marcel Klaassen, Åke Lindström, Ulf Ottosson, Theunis Piersma, Mikael Svensson, Liv Wennerberg, Christer Wiklund, and Susannne Åkesson. We thank Guy Morrison, Brett K. Sandercock, and an anonymous referee for many valuable comments. This project is financed by the Swedish Natural Science Research Council.

\section{APPENDIX. MIGRATION PATTERNS AT THE DIFFERENT SITES (A-Z)}

Site A. 29 June. Ship position was in landfast ice about $5 \mathrm{~km}$ off Iqaluit community in the innermost part of Frobisher Bay. The weather was sunny, with little cloudiness and very good visibility.

Only three radar echoes of birds were tracked, two moving southeast out of the fiord at low altitude $(60-160 \mathrm{~m}$; one identified as an Iceland gull Larus glaucoides), and one moving northwest (track direction $307^{\circ}$ ) at very high altitude $(2960 \mathrm{~m}$ ), with ground speed $16.9 \mathrm{~m} / \mathrm{s}$ and climbing speed $0.5 \mathrm{~m} / \mathrm{s}$. This bird flock (flock characteristics seen from echo signature) was apparently migrating across Baffin Island towards Foxe Basin. Winds at the altitude of these birds were weak $(2.5 \mathrm{~m} / \mathrm{s})$ and from the south.

One possible candidate species for this northwesterly movement is the arctic tern. At least three flocks of arctic terns, with a large proportion of the birds in immature plumage (one year old), were seen migrating northwest from the ship on 26 June when moving towards the entrance of Frobisher Bay through loose pack ice in Davis Strait (approx. $63^{\circ} \mathrm{N}, 60^{\circ} \mathrm{W}$ ).

Site B. 1-2 July. Ship position in mostly open water with some drift ice, about $2 \mathrm{~km}$ off the coast at Cap de Nouvelle-France. This visit coincided with an extensive low-pressure system passing the area, with complete overcast (cloud base at about $100 \mathrm{~m}$ and top at $5000 \mathrm{~m}$ ), rain, strong winds, and poor visibility. Repeated checks showed that the radar screen was saturated by echo clutter from rain and thick clouds, and no echoes from birds were recorded. Neither did visual observations reveal any indications of bird migration taking place in this very poor weather.

Site C. 5-7 July. Ship position in mainly open water with scattered ice floes, about $6 \mathrm{~km}$ off Cape Penrhyn on the eastern coast of the Melville Peninsula. Weather was sunny, with only a few cirrus clouds, good visibility, and weak winds from north and east.

Only six echoes from birds were recorded during 29 hours of intensive radar surveillance. Three of these movements were towards $105-111^{\circ}$ at altitudes of $430-890 \mathrm{~m}$. Remaining movements were towards $32^{\circ}$ (climbing by $0.8 \mathrm{~m} / \mathrm{s}$ at $540 \mathrm{~m}$ altitude), $181^{\circ}$ (at $1860 \mathrm{~m}$ ), and $212^{\circ}$ (flying into land at low altitude, $100 \mathrm{~m}$ ).

While the ship was crossing the dense pack ice in central Foxe Basin on 3 and 4 July, a few small flocks of the following species were observed from the icebreaker to travel in southeasterly directions: red phalarope, long-tailed jaeger, brant Branta bernicla, Canada goose Branta canadensis, snow goose Anser caerulescens, and common eider (males). Furthermore, two red phalaropes were seen migrating ENE at the study site, and additional small parties of this species were encountered on 7 July at the ice edge off Igloolik. Hence, the red phalarope is an important candidate species for the sparse easterly migration at this site. The adult females of this species seem to be among the first to depart on postbreeding migration, possibly on an initial flight step towards Baffin Bay and Davis Strait. Other wader species that were found breeding at this site, like semipalmated plover Charadrius semipalmatus, Baird's sandpiper, and American golden-plover, were not showing any signs of migratory activity.

Site D. 9-11 July. Ship position in pack ice in Creswell Bay, $6 \mathrm{~km}$ off the southern shore of Somerset Island. The weather was partly cloudy (most often sunshine) with moderate NE-E winds (strong winds at surface level). Clouds were seen from a lowpressure system passing to the south of this study site.

Intensity of bird movements was very low, and only 10 radar tracks were recorded in widely scattered directions: three tracks towards the NE quadrant, $46-82^{\circ}$ (climbing by $0.4-1.0 \mathrm{~m} / \mathrm{s}$ at $630-$ $1400 \mathrm{~m}$ altitude); three towards the SE quadrant, $101-159^{\circ}$ (level flight at $810-1500 \mathrm{~m}$ ); three towards the SW quadrant, $201-231^{\circ}$ (at lower altitudes, 150-500 m; these echoes showed indications of relatively slow wing beats like in e.g., jaegers or gulls); and one towards $351^{\circ}$ (steeply climbing by $1.2 \mathrm{~m} / \mathrm{s}$ at $450 \mathrm{~m}$ altitude).

Visual observations indicated distinct migratory tendencies, mainly in red phalarope and long-tailed jaeger. During the crossing through the pack ice of the Gulf of Boothia on 9 July, several flocks (largest flock size was 300 individuals) of red phalarope (adult females) were observed on the water surface as well as on the ice floes, and a few small flocks were seen flying eastwards. Small flocks or single individuals of long-tailed jaeger were seen moving over the Gulf of Boothia (also a few pomarine jaegers) and over Somerset Island (no breeding taking place in the area this year). Among the field observations was also a first record of a small, postbreeding migratory flock of sandpipers (Baird's) at a tundra pool (coinciding with the first records of hatched sandpiper clutches at this site). Breeding shorebirds at this site included American 
golden-plover, black-bellied plover, sanderling, white-rumped sandpiper, and Baird's sandpiper. Gulls, northern fulmars Fulmarus glacialis, and thick-billed murres Uria lomvia seen on foraging flights in the pack ice and geese, ducks, and loons at tundra lakes and along the shores were probably not important in the highaltitude movements primarily recorded by the radar.

Site E. 13-14 July. Ship position in wet landfast ice with some open leads, about $4 \mathrm{~km}$ off the southern shore of Bathurst Island. Weather was sunny, with weak winds on 13 July (2 radar tracks). During the evening and night, weather fronts passed with clouds and rain (no radar work), and on 14 July (5 radar tracks), the sky was only partly cloudy (a few snow showers) and strong northwesterly winds prevailed.

Bird movements at this site were also extremely sparse. Three tracks were recorded of birds descending at low altitude, 50-200 m, towards easterly $\left(43-109^{\circ}\right)$ directions, presumably heading for nearby open leads (loons and jaegers were suspected in these cases). Two tracks were of a rough-legged hawk Buteo lagopus (probably the same individual in the two cases) gliding towards land straight into the wind, after having soared in lee-waves up to $900 \mathrm{~m}$ altitude and at the same time being wind-drifted far out over the ice. Finally, there were two tracks of westerly bird movements, 236-282 ${ }^{\circ}$, at $400 \mathrm{~m}$ altitude in both cases.

Field observations at the tundra camps revealed red knot, sanderling, white-rumped sandpiper, Baird's sandpiper, and longtailed jaeger breeding at low densities, still incubating their eggs. A flock of 15 red knots was seen on the tundra, and two small flocks of arctic terns passed the ship heading east.

Site F. 15-16 July. Ship position in loose pack ice about $3 \mathrm{~km}$ off the shore of northeastern Bathurst Island. The weather was characterized by strong and cold northwesterly winds, partly cloudy skies with snow showers or snow drizzle, and spells of low-level fog banks and sunshine.

The sky was almost devoid of bird traffic. Only two tracks were recorded, one towards $312^{\circ}$ at $870 \mathrm{~m}$ height and one towards $108^{\circ}$ at $360 \mathrm{~m}$.

Low-altitude movements at the shore of long-tailed jaegers (including a flock of 22 individuals), arctic terns, ivory gulls Pagophila eburnea, glaucous gulls Larus hyperboreus, and oldsquaws were recorded by visual observations, but there were no indications of a distinct migratory passage.

Site G. 19 July. Ship position in pack ice about $50 \mathrm{~km}$ west of Boothia Peninsula (short stop for engine service). Snowfall stopped and the clouds disappeared, leaving clear skies above the low-level fog during the final two hours of the observation period. Winds were very weak.

Four tracks of high-altitude (1680-2950 m) bird movements were recorded after the weather improvement, indicating the start of a regular migratory passage. All tracks were in similar directions, $118-128^{\circ}$.

Site H. 20-22 July. Ship position in pack ice about $40 \mathrm{~km}$ off the northwestern shores of King William Island. On 20 July, the sky was covered by rather thin high clouds (mainly altocumulus, with ceiling at or above $2000 \mathrm{~m}$ ), often allowing the position of the sun to be determined. Winds were of moderate strengths $(4-9 \mathrm{~m} / \mathrm{s})$ from the east. A cold front passage took place during the night with extensive cloudiness and rain/drizzle. During 21 July, the weather showed a steady improvement, and in the late afternoon and evening there were clear skies, sunshine, and excellent visibility. Weak winds $(1-4 \mathrm{~m} / \mathrm{s})$ from the north prevailed on this day. Except for the final clear afternoon and evening hours, there was low-level fog or mist at the ship throughout the stay at this site.

For the first time during the expedition, we encountered migration of a rather high intensity, and a total of 50 radar tracks were recorded. The migration pattern was bimodal, with main peaks of track directions towards west and southeast (Fig. 2, Table 2):

1. The westerly movements showed track directions in the interval $211-349^{\circ}$, with a mean at $270^{\circ}$. Westerly migration dominated on 20 July, making up 23 of the 28 tracks recorded on this day, when there were tailwinds from the east. In contrast, on $21 \mathrm{July}$, when winds were less favorable, only 9 out of 22 tracks belonged to the westerly category of movement. The majority of the flocks in the west-migrating category ( 21 of the 32 tracks) traveled at altitudes between 400 and $800 \mathrm{~m}$, and there was only a single record above $1000 \mathrm{~m}$ (max. altitude $1030 \mathrm{~m}$ ). Most of the westerly migration took place between 0800 and 1500 (local time) on both days.

2 . There were 18 tracks of easterly migration, with directions ranging from $71^{\circ}$ to $176^{\circ}$ and a mean direction of $132^{\circ}$. Only five of these tracks were recorded on 20 July, when headwinds prevailed, while the rest of the birds passed on $21 \mathrm{July}$, when the northerly winds gave a small positive contribution to their ground speeds. Seven of the tracks were at altitudes exceeding $1000 \mathrm{~m}$, with the two highest at 3610 and $3670 \mathrm{~m}$. The southeasterly migration took place mainly between 1400 and 2000 (local time).

Because of the frequent low-altitude fog and mist at the ship, no visual identifications could be made. However, observers from the field camps on the tundra of King William Island reported a multitude of resting flocks (flock sizes mainly $3-15$, sometimes 20 individuals) of adult shorebirds, sometimes with mixed species composition. Most of these shorebirds had apparently started postbreeding migration. The following species were most common: American golden-plover (a flock of seven was seen departing towards southeast), semipalmated sandpiper, Baird's sandpiper, white-rumped sandpiper, dunlin Calidris alpina, and red phalarope. In addition, several other species were recorded in smaller numbers: red knot, buff-breasted sandpiper, pectoral sandpiper, sanderling, ruddy turnstone, black-bellied plover, and stilt sandpiper. Many breeding shorebirds had small chicks, and some were still incubating egg clutches. It is highly probable that the southeasterly movements were mainly due to some of these shorebird species.

Another species that may have been involved in important migratory movements is the long-tailed jaeger, which was observed in scattered parties on King William Island. Observations during the following days of the expedition of some westerly movements of this species in the straits south of Victoria Island, and of significant numbers roaming the open waters of Amundsen Gulf (cf. below), make the long-tailed jaeger a possible candidate species for the westerly migration. However, we speculate that some of the shorebird species, as well as arctic terns, may also have been involved in these movements.

One should be aware that even if the number of radar tracks recorded at this site (50 tracks) is modest, it indicates migration of sizeable dimensions, taking into account the limited cover of the 
radar (covering an effective frontal width of $10-15 \mathrm{~km}$ ) and the facts that only a minority of the flocks within the radar range are tracked and each target normally is a flock of migrants. One may provisionally "guesstimate" that the total migration traffic across the $200 \mathrm{~km}$ frontal width at Victoria Strait may have involved several tens of thousands of birds during the two study days (assuming that about 10\% of all flocks passing within the radar cover range were tracked and that mean flock sizes were 10-20 birds).

Site J. 23-25 July. Ship position in open water, $2 \mathrm{~km}$ from the shore in Falaise Bay at Wollaston Peninsula, Victoria Island. The weather was partly cloudy with stratocumulus clouds (ceiling about $500 \mathrm{~m}$ ), but the sun was most often visible, even through the rather thin clouds. Strong westerly winds $(8-13 \mathrm{~m} / \mathrm{s})$ prevailed throughout the stay.

There was regular migration of moderate intensity in easterly directions. Of the 25 radar tracks recorded, 21 were in easterly directions and only four in the west sector $\left(181-268^{\circ}\right)$. The easterly movements were rather scattered, with some tendency of concentration between $70^{\circ}$ and $100^{\circ}$ (Fig. 2). Migration seemed to take place on a broad front, with tracks over both land and sea, and with no apparent responses to the shoreline. Altitudes were modest, with 11 tracks between 250 and $500 \mathrm{~m}$; only four tracks were above $1000 \mathrm{~m}$, the highest at $2090 \mathrm{~m}$. The easterly migrants were assisted by strong tailwinds, which added $4-13 \mathrm{~m} / \mathrm{s}$ extra speed to their air speeds in 16 cases. Consequently, ground speeds were often fast, exceeding $20 \mathrm{~m} / \mathrm{s}$ in 13 cases, with a maximum of $30.8 \mathrm{~m} / \mathrm{s}$. Most of the migration was recorded between 1700 and 2300 (local time).

Several of the shorebird species recorded at King William Island (site $\mathrm{H}$ ) were noted at this site as well, but at much lower densities. A few flocks of pectoral and buff-breasted sandpipers were recorded on the tundra. Most of the radar tracks were probably migrating shorebirds, although one track towards due east was identified as a group of three sandhill cranes Grus americana.

Site K. 26-28 July. Ship position in open water about $2 \mathrm{~km}$ off the mainland coast (Albert Bay) at Amundsen Gulf. On 26 July, the weather was unstable with rain and fog in the morning, but improved with reduced cloudiness in the afternoon and evening. A new spell of rain and fog occurred during the following night and early morning, and on 27 July the sky was mostly overcast. Winds at low altitude were mostly westerly $(3-6 \mathrm{~m} / \mathrm{s})$, but at high altitude (above $1000 \mathrm{~m}$ ) easterly winds prevailed. On $27 \mathrm{July}$, the wind shifted towards the east and increased in strength at low altitudes as well.

Movements at altitudes above $250 \mathrm{~m}$ were very sparse, and only six radar tracks were recorded in scattered directions (cf. Table 2): two towards the east $\left(88-130^{\circ}\right)$ in westerly winds (altitudes 360 $470 \mathrm{~m})$, two towards the north $\left(330-1^{\circ}\right)$ in southeasterly winds (altitudes 1780-2240 m), and two towards west-southwest (247$255^{\circ}$ ) in northeasterly winds (altitudes 2070-2270 m).

In contrast, bird movements at low altitudes over the sea were abundant, and 67 radar tracks were recorded below $250 \mathrm{~m}$. In fact, 50 tracks were less than $60 \mathrm{~m}$ above the sea surface. According to visual observations, these movements consisted of two main components: (1) several flocks of common eider males (and also some small flocks of oldsquaws) were seen on molt migration towards the west (one track was also identified as a flock of 120 common eider males), and (2) small, scattered groups of long-tailed jaegers were flying in more variable directions over the sea. Twelve of the radar tracks (including the identified eider flock) had air speeds as high as $16-22 \mathrm{~m} / \mathrm{s}$, and these tracks are likely to reflect flocks of migrating ducks. All except one of these fast flocks were traveling towards the west $\left(249-315^{\circ}\right)$. Targets with air speeds in the interval $8-16 \mathrm{~m} / \mathrm{s}$ are more likely to be due to long-tailed jaegers (and this identification was sometimes indicated also by the wingbeat signature of the radar echoes), and directions of 44 such targets were recorded in all four quadrants, although with a prevalence of westerly directions (NE: 8, SE: 7, SW: 18, NW: 11). These movements were possibly a combination of foraging and migratory flights. While common eider flocks were seen from the ship migrating westwards at close range, the jaegers occurred farther offshore, at least $8 \mathrm{~km}$ from the shore and beyond visual range.

According to observations from the field camps, the tundra at this site was remarkably empty of birds. Of shorebirds, only the semipalmated sandpiper was recorded. The scarcity of high-altitude migration is in accordance with the absence of observed shorebirds at this site.

Site L. 28-29 July. Ship position in open water 2-3 km off the shore of southwestern Banks Island. The edge of the pack ice in the Beaufort Sea was about $100 \mathrm{~km}$ to the west of our position. The weather was mostly sunny with scattered cumulus clouds, and winds were blowing from the east with moderate strength $(6-10 \mathrm{~m} / \mathrm{s})$. Radar echoes of insects (swarms of mosquitoes) were regularly registered at altitudes up to $800 \mathrm{~m}$, drifting westwards with the winds.

Movements at altitudes above $250 \mathrm{~m}$ were sparse at this site also (Table 2), and only 10 radar tracks were recorded at altitudes between 320 and $1520 \mathrm{~m}$. Of these, there was one track in each of the SE, SW, and NW quadrants, while seven tracks were towards northeast $\left(7-58^{\circ}\right)$. One of these tracks (towards $18^{\circ}$ ) was identified as a flock of three long-tailed jaegers, first climbing in soaring flight up to $800 \mathrm{~m}$ and then departing inland (across Banks Island) in more level flight (overall climbing speed during nine minutes of tracking was $0.6 \mathrm{~m} / \mathrm{s}$ ). Very similar characteristics of a distinct climb (probably soaring flight), succeeded by more level flight when departing across land, were recorded for five of the other northeasterly $\left(28-58^{\circ}\right)$ tracks, which indicates that these tracks were probably also due to long-tailed jaegers. The average altitudes (including the identified track) ranged between 370 and $1520 \mathrm{~m}$. In the case with highest altitude, the birds soon stopped climbing, and the major part of the track showed level or slightly descending flight (overall vertical speed of $0.1 \mathrm{~m} / \mathrm{s}$ ). The other tracks showed substantial gains in altitude, with overall climb rates of $0.6-1.5 \mathrm{~m} / \mathrm{s}$.

Of the 23 low-altitude $(<250 \mathrm{~m})$ tracks, one was identified as a gyrfalcon Falco rusticolus moving southeast at $170 \mathrm{~m}$ height over the shore mainly by flapping and gliding flight, and two were yellow-billed divers Gavia adamsii flying from the sea into land (towards $4^{\circ}$ and $57^{\circ}$ ) at 150 and $180 \mathrm{~m}$ altitude (with air speeds of 18.5 and $19.2 \mathrm{~m} / \mathrm{s}$ ). These tracks probably reflected local movements of breeding birds rather than migratory flights. Most of the low-altitude tracks were recorded below $100 \mathrm{~m}$ far out over the sea, and they presumably reflected the same type of movements by longtailed jaegers as recorded at site $\mathrm{K}$ on the opposite shore of Amundsen Gulf (a presumption supported by visual observations of 
some small parties or single individuals of long-tailed jaegers during the ship journey between sites $\mathrm{K}$ and L). Fifteen such tracks with air speeds of $10-16 \mathrm{~m} / \mathrm{s}$ were directed into all four quadrants (NE: 3, SE: 6, SW: 4, NW: 2) with some dominance for southerly movements.

An attempt was made to estimate the density of these targets by counting the number of radar echoes in the $6-16 \mathrm{~km}$ range when scanning $90^{\circ}$ or $120^{\circ}$ sectors low over the open sea. Six such counts gave density estimates of $2-8$ targets per $100 \mathrm{~km}^{2}$ (corresponding densities at site $\mathrm{K}$ were probably higher, but were not estimated quantitatively). Assuming that these echoes were mainly longtailed jaegers, most often flying a few together (such a flock will correspond to one radar echo) over an area of at least $40000 \mathrm{~km}^{2}$ at Amundsen Gulf westwards to approximately longitude $128^{\circ} \mathrm{W}$, as indicated by our visual observations, these densities indicate that several thousand jaegers had gathered in this postbreeding concentration area.

Only a few shorebirds were seen on the tundra, including a flock of newly fledged buff-breasted sandpipers at the shore. The easterly winds may have inhibited shorebird migration towards easterly directions (cf. below).

Site M. 31 July-1 August and 6-7 August. Ship position in open water north of Tuktoyaktuk, about $27 \mathrm{~km}$ from the nearest shoreline. This site was visited during two periods, first on 31 July and 1 August (rotation of expedition participants) and later on 6 and 7 August (refueling of ship). On 31 July, there were clear skies with sunshine, good visibility, and southwesterly winds $(7-9 \mathrm{~m} / \mathrm{s})$. The fine weather continued during the next day, although with a partially cloudy sky (altocumulus) and westerly winds (about $10 \mathrm{~m} / \mathrm{s}$ ). On 6 and 7 August, weather was also fine, with mainly clear skies and good visibility. Winds, blowing from the southeast, were strong (exceeding $10 \mathrm{~m} / \mathrm{s}$ ) at low altitudes (up to $400 \mathrm{~m}$ ), but weaker (2$7 \mathrm{~m} / \mathrm{s}$ ) at higher levels.

Mass migration took place towards the east, with highest intensity on 31 July and 1 August, when 99 of the 124 tracks were recorded. There was a distinct concentration of directions in the interval $70-110^{\circ}(64 \%$ of all tracks), and the mean direction was almost due east, $87^{\circ}$ (Fig. 2, Table 2). Migration in westerly directions was negligible, with only four tracks in this sector (Fig. 2). Tracks at altitudes below $250 \mathrm{~m}$ comprised only $10 \%$ of the total, while tracks between 250 and 1000 m constituted the majority $(61 \%)$. Movements above $1000 \mathrm{~m}$ were regular (29\% of all tracks), with the highest flock at $3560 \mathrm{~m}$ altitude. The majority (69\%) of the migrants passed in approximately level flight with vertical speeds between -0.4 and $0.4 \mathrm{~m} / \mathrm{s}$. Of the remainder, $17 \%$ were climbing by at least $0.4 \mathrm{~m} / \mathrm{s}$, and $14 \%$ were descending, with a vertical speed below $-0.4 \mathrm{~m} / \mathrm{s}$. Air speeds were concentrated in the interval $10-$ $18 \mathrm{~m} / \mathrm{s}(90 \%$ of all tracks) with a mean at $14.0 \mathrm{~m} / \mathrm{s}$. The migrants generally had a fair amount of wind assistance, so the average ground speed $(17.2 \mathrm{~m} / \mathrm{s})$ was clearly faster than the air speed, and ground speeds were mainly $(81 \%)$ in the interval $12-24 \mathrm{~m} / \mathrm{s}$. Migration was recorded throughout the day and night, without any distinct peak in timing.

The radar echoes often showed multiple peaks and were spread out in space, indicating that most targets were flocks, often subdivided into fractions. Five tracks were identified, and they were all shorebirds: in one case only a single individual, but in the other cases flock formations of $11,12,30$, and 55 birds. One of these flocks was identified to species: 11 American golden-plovers traveling towards $58^{\circ}$ at $585 \mathrm{~m}$ altitude (air speed $14.1 \mathrm{~m} / \mathrm{s}$ ). The other identified shorebird targets had track directions of $91-113^{\circ}$ and were flying at altitudes between 380 and $2260 \mathrm{~m}$. Visual observations from the ship included the following species of shorebirds (all migrating towards the east): American goldenplover (several flocks), black-bellied plover, pectoral sandpiper, and red knot. There can be little doubt that the eastward stream of migrants was composed mainly of shorebirds. Only very sparse, low-altitude movements over the sea were seen from the ship; these birds were northern pintails Anas acuta (a few flocks towards the east) and glaucous gulls and Thayer's gulls Larus thayeri (variable directions), but there were no long-tailed jaegers (in contrast to the Amundsen Gulf area and farther east).

Site N. 2-3 August. Ship position in open water with scattered drifting floes of ice about $100 \mathrm{~km}$ north of Herschel Island. There was open water between the ship's position and the mainland, while the edge of the pack ice of the Beaufort Sea was immediately to the north of the ship's position. Radar operation took place continuously during almost a full day and night (from 0300 local time to 0100 the next day). The position of the sun could be seen throughout this period, through high, thin clouds during the "night" and through low-level fog during the day. Winds were mostly variable and weak $(1-4 \mathrm{~m} / \mathrm{s})$ until the final evening, when they were growing to moderate strength $(5-7 \mathrm{~m} / \mathrm{s})$ from the west.

A steady flow of easterly migration continued throughout the observation period. Out of a total of 34 tracks, 30 were towards easterly directions, with a concentration between $80^{\circ}$ and $120^{\circ}$ ( $65 \%$ of all tracks; Fig. 2, Table 2 ). The migratory passage generally took place at very high altitudes, and this site had the highest mean altitude, close to $2 \mathrm{~km}$, of all sites visited during the expedition. There were only nine tracks below $1000 \mathrm{~m}$ (only one below $250 \mathrm{~m}$ ), with most flocks $(n=22)$ between 1500 and $3000 \mathrm{~m}$, and the highest record was at $3950 \mathrm{~m}$. Air speeds were rather variable and high, mostly $10-22 \mathrm{~m} / \mathrm{s}$, with a mean of $16.1 \mathrm{~m} / \mathrm{s}$ (Table 2 ). The relatively fast air speeds may be related to the high altitudes. Migration continued throughout the observation period without any distinct peaks in time.

One of the high-altitude targets tracked by radar was spotted through the telescope: a flock (subdivided into several fractions) of about 110 shorebirds in formation flight (direction $84^{\circ}$, altitude $2080 \mathrm{~m}$, and air speed $13.2 \mathrm{~m} / \mathrm{s}$ ). Other birds seen from the ship, and more likely to take part in the low-altitude westward movements, were an unidentified loon (Gavia sp.), two glaucous gulls, one longtailed jaeger, and a flock of ducks.

Site O. 3-5 August. Ship position in open water about 7-8 km from the mainland shore and from Herschel Island. The ship moved from an anchoring position west of the island to a new position east of the island halfway through the visit to this site. Above frequent low-level fog or fog banks at the ship, skies were mainly clear. Southerly winds prevailed, with wind direction varying between southeast and southwest, and wind speeds were most often between 6 and $11 \mathrm{~m} / \mathrm{s}$.

The highest migration intensity during the expedition was recorded at this site, with $90 \%$ of the tracks in easterly directions. The easterly mass migration was directed mainly in the interval 60- 
$140^{\circ}$ (85\% of all easterly tracks; Fig. 2) with an overall mean direction of $104^{\circ}$ (Table 2). Altitudes were moderate, with the majority $(51 \%)$ between 250 and $1000 \mathrm{~m}$, while only $13 \%$ were below $250 \mathrm{~m}$. Altitude for $30 \%$ of all tracks fell between 1000 and $2000 \mathrm{~m}$, while $6 \%$ were above $2000 \mathrm{~m}$, with the highest track at $3250 \mathrm{~m}$. Comparatively large proportions of the migrants were tracked while climbing at vertical speeds exceeding $0.4 \mathrm{~m} / \mathrm{s}(26 \%)$, or while descending by vertical speeds below $-0.4 \mathrm{~m} / \mathrm{s}$ (35\%), with the remaining proportion (39\%) in approximately level flight. A vast majority of air speeds ( $92 \%$ ) fell within $8-18 \mathrm{~m} / \mathrm{s}$, with a mean of $13.0 \mathrm{~m} / \mathrm{s}$. Most migrants were hindered rather than assisted by the southerly winds, so that in $74 \%$ of all cases the ground speed was slower than the air speed. The overall mean ground speed was only $11.2 \mathrm{~m} / \mathrm{s}$, which is slow in comparison with most other sites (Table 2). Intensive migration occurred mainly during the night and morning until about noon, while activity was distinctly lower in the afternoon, between 1200 and 2000 .

There can be little doubt that shorebirds dominated greatly in the migratory movements. Observations at a field camp close to the shore revealed large-scale shorebird migration in easterly directions. By far the most numerous species taking part in this migration was semipalmated sandpiper, of which several thousand birds were seen during the two-day stay. Other species participating, although in smaller numbers, were American golden-plover, black-bellied plover, semipalmated plover, Baird's sandpiper, stilt sandpiper, and pectoral sandpiper. The area was evidently used as a stopover area for shorebirds, and we observed both arriving and departing flocks, as well as flocks migrating through the area. Resting flocks of the above-mentioned species were most frequently observed along the shorelines during the afternoon. This timing agrees with the temporal pattern suggested by the radar observations: migratory flights during the night and morning, and resting and stopover during the afternoon. At the ship, easterly movements of shorebirds were detected. Several flocks consisting of two to five individuals of both small and larger Calidris species were observed. Also, a few small flocks (3-35 birds) of red-necked phalarope were seen near the ship. Furthermore, a few common redpolls Carduelis flammea (up to eight in a flock) were seen passing the ship. One of the westerly tracks, moving at $110 \mathrm{~m}$ altitude towards $238^{\circ}$, was identified as a long-tailed jaeger.

Site P. 7-8 August. Ship position was in open water about $5 \mathrm{~km}$ west (leeward side) of the Baillie Islands at Cape Bathurst. Weather was sunny with clear skies, but easterly winds were blowing with gale force, $15-20 \mathrm{~m} / \mathrm{s}$. The skies were empty of migrating birds, and only one radar echo was tracked during ten hours of radar surveillance time.

Site R. 10-12 August. Ship position in melting ice with pools of water and some open leads, about $7 \mathrm{~km}$ off the outlet of Parker River, northeastern Banks Island. Low-level fog, which was sometimes dense, often surrounded the ship. Sometimes sunshine penetrated through the fog, and on occasions when the fog lifted, skies were partly cloudy (high clouds) or clear with sunshine. At altitudes where the birds were flying, winds were mainly northerly and weak or moderate in strength $(3-7 \mathrm{~m} / \mathrm{s})$ until the final day, when they shifted to a southeasterly direction and were reduced in strength $(2-3 \mathrm{~m} / \mathrm{s})$. At ground level, it was mostly calm.

Radar was operated for a total of 33.5 hours (Table 1) during the two-day visit at this site, and bird movements were regular and of rather high intensity, especially during the two nights and mornings. There was a concentration of movements in northerly directions, and $59 \%$ of all tracks were in the sector $310-50^{\circ}$. The remaining tracks were widely scattered, with $20 \%$ towards easterly directions $\left(50-180^{\circ}\right)$ and equally many towards the west $(220-$ $300^{\circ}$; Fig. 2). The bird traffic took place at moderate heights above the fog, with $74 \%$ of all tracks between 250 and $1000 \mathrm{~m}$ (there was no track below $250 \mathrm{~m}$ ). There were only three tracks above $1500 \mathrm{~m}$, with the highest at $2830 \mathrm{~m}$, and all three were towards westerly directions $\left(235-267^{\circ}\right)$. There was a rather even distribution between climbing (32\%), descending (24\%), and level (44\%) tracks, as classified on the basis of vertical speed being greater than $0.4 \mathrm{~m} / \mathrm{s}$, below $-0.4 \mathrm{~m} / \mathrm{s}$, or between -0.4 and $0.4 \mathrm{~m} / \mathrm{s}$, respectively. The majority (75\%) of all air speeds were in the interval $10-16 \mathrm{~m} / \mathrm{s}$. There were only four cases of fast-flyers with air speeds of 20 $24 \mathrm{~m} / \mathrm{s}$, and two of these were towards the north and two towards southeast. The birds gained some wind assistance, i.e., ground speed exceeded air speed, in 58\% of the cases, whereas ground speed was reduced in comparison with air speed in the remaining cases. Since winds were mostly weak, the mean ground speed was rather similar to the mean air speed (Table 2). There was a distinct peak of migratory activity between 2300 and 0600 (local time), when $81 \%$ of the tracks were recorded.

According to observations reported from the field camps on northern Banks Island, there were some flocks of ruddy turnstones, buff-breasted sandpipers, and red phalaropes resting in the area. At the ship, we observed one flock each of ruddy turnstone, sanderling, and pectoral sandpiper. A flock of 58 king eiders Somateria spectabilis observed close to the ship may indicate the identity of the few faster flying tracks recorded. Long-tailed jaegers may have been involved in the remarkable northerly movements. This species was observed at the field camps, although it was not recorded on migration. However, during the voyage along the west and north coasts of Banks Island preceding the radar observations at site $\mathrm{R}$, scattered single individuals of jaegers (mainly long-tailed), as well as a few arctic terns, were observed. This conclusion would also fit with the observations of northward departures of long-tailed jaegers across Banks Island at site $\mathrm{K}$, and the possibility of northerly flights from the Amundsen Gulf region (see sites $\mathrm{K}$ and $\mathrm{L}$ ). The northerly migrants were traveling towards M'Clure Strait (where the ice cover had recently broken up) and Melville Island. Of the 46 northerly tracks $\left(310-50^{\circ}\right), 10$ were at altitudes of $250-500 \mathrm{~m}, 24$ at $500-1000 \mathrm{~m}$, and 10 at $1000-1500 \mathrm{~m}$, with the highest at $1480 \mathrm{~m}$. Of these northerly tracks, $14(30 \%)$ were descending $\left(\mathrm{V}_{\mathrm{z}}<-0.4 \mathrm{~m} / \mathrm{s}\right)$, while there were only five $(16 \%)$ descending tracks in other directions. This may suggest that at least some of the northerly migrants were approaching the end of a flight step.

Site S. 13-15 August. Ship position was first in pack ice about $10 \mathrm{~km}$ from the coast at Skene Bay, southeastern Melville Island. On the second day, the ship was moved to open water, anchoring at the entrance of Skene Bay $3 \mathrm{~km}$ offshore. Weather was most often sunny, with clear skies and very good visibility, although there was temporary cloud cover during part of one day. Winds were mostly northerly to northwesterly and of moderate strength $(3-7 \mathrm{~m} / \mathrm{s})$.

Although radar coverage during the two-day visit was similar to that at the preceding site $(\mathrm{R})$, fewer than half as many tracks were recorded at this site, demonstrating a clearly lower migration traffic 
rate. The 32 tracks were scattered in widely different directions (Fig. 2), although one may discern three main sectors, towards northerly $\left(9\right.$ tracks at $\left.320-30^{\circ}\right)$, easterly $\left(10\right.$ tracks at $\left.50-180^{\circ}\right)$, and westerly $\left(13\right.$ tracks at $\left.190-290^{\circ}\right)$ directions. Most tracks (17 out of 32) were at altitudes between 250 and $1000 \mathrm{~m}$, but there were also six tracks below $250 \mathrm{~m}$ and nine tracks above $1000 \mathrm{~m}$. Of these nine tracks, four (at 3070, 2270, 1700, and $1290 \mathrm{~m}$ ) were in easterly directions $71-111^{\circ}$, four $(1680,1300,1170$, and $1040 \mathrm{~m})$ had westerly courses $200-289^{\circ}$, and only one $(1080 \mathrm{~m})$ was towards the north $\left(356^{\circ}\right)$. Considering all 32 tracks, there was an even balance between climbing $\left(\mathrm{V}_{\mathrm{z}}>0.4 \mathrm{~m} / \mathrm{s}\right)$ and descending cases $\left(\mathrm{V}_{\mathrm{z}}<-0.4 \mathrm{~m} / \mathrm{s}\right)$ with nine tracks in each category, in addition to 14 tracks in approximately level flight. However, of the nine northerly tracks, four were descending and only one was climbing, while of the 13 westerly tracks, five were climbing and only two were descending. Of the easterly tracks, there were three cases each of climb and descent. Air speeds were $10-18 \mathrm{~m} / \mathrm{s}$ in $90 \%$ of the cases. It was equally common that winds caused the ground speed to exceed the air speed as vice versa; as a result, mean ground speed was very similar to mean air speed (Table 2). There was a distinct peak in migratory activity between 2200 and 0800 (local time), when $88 \%$ of the tracks were recorded.

Comparing this site with the preceding site $\mathrm{R}$, one may tentatively identify three similar categories of migration, towards northerly, easterly, and westerly sectors. While the northerly category at site $\mathrm{R}$ dominated, with $59 \%$ of the tracks, at site $\mathrm{S}$ it was much reduced in extent, involving only $28 \%$ of the tracks. Furthermore, descending flights were most common in this category, and only one flight exceeded $1000 \mathrm{~m}$ at site S. This indicates that the northerly migration may peter out as one moves northeast from site $\mathrm{R}$ to site $\mathrm{S}$. The easterly and westerly migratory categories were of a similar magnitude at sites $\mathrm{R}$ and $\mathrm{S}$, and the occurrence of high altitudes in both groups indicates that they make up a sparse but recurrent migration pattern in the region of Melville and northern Banks Islands. The westerly group of migrants will presumably cross large expanses of the Beaufort Sea, traveling towards Alaska, while the easterly migrants may join the southeasterly migration stream recorded in more southeasterly regions (cf. sites $\mathrm{H}, \mathrm{Y}$, and Z).

According to observations from the ship and at the field camps on Melville Island, black-bellied plover, sanderling, white-rumped sandpiper, Baird's sandpiper and arctic tern were among the candidate species to be involved in the migratory movements observed. Jaegers may also have made up a part of the recorded tracks, as a concentration of about 50 jaegers, among which were 25 pomarine, eight parasitic, and five long-tailed jaegers, and a small number of Sabine's and Ross's gulls were found east of the radar site in Viscount Melville Sound.

Site T. 18-20 August. Ship position in open water in Hospital Bay, $3 \mathrm{~km}$ from the shore at northern Ellef Ringnes Island. This was the approximate position of the North Magnetic Pole at the time of the visit. The weather was characterized by good visibility and weak winds, but cloud conditions varied a lot, from almost clear skies to complete overcast with snow drizzle or showers. Winds at higher altitudes were mostly easterly, with speeds up to $3-5 \mathrm{~m} / \mathrm{s}$.

Since this site at the North Magnetic Pole was of special interest with respect to the orientation of migrating birds, radar surveillance was extensive to maximize the number of tracks of bird movements. However, bird migration was almost negligible, and a mere three tracks were recorded during 42.5 hours of radar operation. Two tracks moved towards the north $\left(4^{\circ}\right.$ and $\left.6^{\circ}\right)$ at 1160 and $780 \mathrm{~m}$ altitude, while one track moved towards $143^{\circ}$ at $260 \mathrm{~m}$.

Bird life was extremely sparse at this northerly island. Several seabird species seen around the ship are not likely to be candidates for the recorded tracks. These were ivory gull, glaucous gull, northern fulmar, black guillemot Cepphus grylle, and thick-billed murre. Other species recorded near the ship and at field camps were black-bellied plover, Baird's sandpiper, red phalarope, arctic tern, and snow bunting Plectrophenax nivalis.

Site U. 22-23 August. Ship position in open water with icebergs at the mouth of Muskoxen Fiord, a few kilometers from Cape Storm, southern Ellesmere Island. Cloudiness of variable extent prevailed, but there were always patches of blue sky to be seen. Winds, from the northwest, were strong, up to $15-20 \mathrm{~m} / \mathrm{s}$ at the ship and $8-$ $13 \mathrm{~m} / \mathrm{s}$ at the birds' altitudes.

The migration traffic rate was very low, and only seven radar tracks were recorded, three in westerly directions $237-283^{\circ}$ and four towards southeast $129-148^{\circ}$. All tracks were at rather high altitudes, six of them between 680 and $1480 \mathrm{~m}$, and one track (towards $148^{\circ}$ ) was at the very high altitude of $3430 \mathrm{~m}$. The indication of a bimodal migration pattern, towards west-southwest and southeast, is noteworthy.

Larger concentrations of northern fulmars and black guillemots were recorded in the waters close to the ship, but neither species is a likely candidate for the recorded high-altitude migration. Two migrating flocks of brant on a southeasterly direction were observed the day before the radar observations started. Other migratory birds observed at the field camps and from the ship were snow goose, eight species of shorebirds, arctic tern, and pomarine and parasitic jaegers.

Sites V, W, and X. 25-28 August. Ship positions in open water in Dundas Harbour, southeastern Devon Island (site V), at Pond Inlet, northern Baffin Island (site W, short visit) and at Cape Adair, northern Baffin Island (site $X$, very short visit). High mountains surrounded the ship at sites $\mathrm{V}$ and $\mathrm{W}$, and ground echoes up to rather high elevations prevented efficient radar tracking. The weather was mostly fine, with only moderate cloudiness, good visibility, and weak winds.

Partly as a consequence of the unsuitable topographical conditions for radar tracking at sites $\mathrm{V}$ and $\mathrm{W}$, only two radar tracks were recorded, one towards $343^{\circ}$ at $1560 \mathrm{~m}$ altitude and one towards $297^{\circ}$ at $80 \mathrm{~m}$, both at Devon Island (site V).

The waters around south Devon and northern Baffin Islands held large numbers of seabirds, such as northern fulmar, black-legged kittiwake, glaucous gull, Thayer's gull, dovekie Alle alle, thickbilled murre, and black guillemot. Significant numbers of resting shorebirds were recorded at Dundas Harbour, with white-rumped and Baird's sandpipers being the most numerous. Other shorebirds observed at this site were American golden-plover, black-bellied plover, purple sandpiper Calidris maritima, and ruddy turnstone. At northern Baffin Island, flocks of red phalaropes were encountered resting on the sea, in total 83 birds. At the comparatively species-rich Dundas Harbour area, a few passerine species were recorded as well, including migrants such as horned lark Eremophila alpestris, northern wheatear Oenanthe oenanthe, lapland longspur Calcarius lapponicus, and snow bunting. 
Site Y. 30-31 August. Ship position in loose pack ice $5 \mathrm{~km}$ off Cape Hooper in Home Bay, eastern Baffin Island. The weather was mainly overcast, but the moon was visible through the rather thin clouds at night. Occasionally, thicker clouds with snow showers passed the study site. Winds were blowing from the west or north with speeds of 4-6 m/s. At this and the next site, the nights were dark for the first time during the expedition, darkness lasting approximately from 2100 to 0300 (local time).

There was a regular although not very intensive southeasterly or southerly migration, and 17 (74\%) of the 23 tracks recorded at this site were in the sector $110-210^{\circ}$. Altitudes were moderate, with 15 tracks between 250 and $750 \mathrm{~m}$. There were three tracks below $250 \mathrm{~m}$, and equally many above $1000 \mathrm{~m}$. Of these high-altitude flights, the two highest, at 3430 and $1290 \mathrm{~m}$, were towards irregular directions, $32^{\circ}$ and $273^{\circ}$, respectively (Fig. 2). Most flights were approximately level (14), but there were also cases of descent (5) and ascent (4). Air speeds were mostly in the range $9-15 \mathrm{~m} / \mathrm{s}(87 \%$ of the tracks). The birds did benefit from the wind, in the sense that the ground speed exceeded their air speed, in 17 of the 23 cases. All tracks were recorded between 2200 and 0700 (local time), most of them $(70 \%)$ during the early morning hours (0300 to 0600$)$.

The only shorebirds seen at field camps on Baffin Island were white-rumped and purple sandpipers in small numbers. From the ship, a few small flocks (2-23 individuals) of red phalaropes were observed. A few pomarine jaegers were also seen in the waters off east Baffin. In addition to the above-mentioned species, passerines may also have been involved in the migratory movements. This was suspected on the basis of echo signatures of some of the targets at this as well as the last site $(\mathrm{Z})$. The only passerine species observed at field camps were American pipit Anthus rubescens and snow bunting, but a few other species likely to migrate over southern Baffin were observed farther north on Baffin Island and Devon Island (cf. site V).

Site Z. 3 September. Ship was back at site A, now anchored in open water $5 \mathrm{~km}$ off Iqaluit. Snow and rain showers passed on several occasions, but there were also periods with good visibility and blue (during the day) or starry (during the night) skies. The winds were strong, mostly $13-16 \mathrm{~m} / \mathrm{s}$, from the northwest.

The distribution of track directions was similar to that at the preceding site, and $28(90 \%)$ of the 31 tracks were in the interval $110-210^{\circ}$ (Fig. 2, Table 2). That track directions remained similar at sites $\mathrm{Y}$ and $\mathrm{Z}$, in spite of the differences in winds, is an indication that the migrants probably compensated for wind drift (Green et al., unpubl. data). Altitudes were between 250 and $750 \mathrm{~m}$ in 18 cases, while there were eight tracks below $250 \mathrm{~m}$ and four tracks above $1000 \mathrm{~m}$. The latter four tracks, at altitudes $1370-1940 \mathrm{~m}$, were in the southeastern quadrant, with track directions $133-163^{\circ}$. Descending and level flights were equally many (12 each) while the number of climbing flights was somewhat smaller (7). The main interval of air speeds was $8-18 \mathrm{~m} / \mathrm{s}$ ( $94 \%$ of the tracks). In all except four cases, the birds gained in speed from the strong winds, and average ground speed was as high as $20.2 \mathrm{~m} / \mathrm{s}$. Ground speed even exceeded $30 \mathrm{~m} / \mathrm{s}$ in four cases: these migrants were traveling towards $133-163^{\circ}$ in due tailwinds of $14-19 \mathrm{~m} / \mathrm{s}$, resulting in ground speeds between $30.2 \mathrm{~m} / \mathrm{s}$ and $37.7 \mathrm{~m} / \mathrm{s}$. All tracks except two were recorded between 2000 and 0700 (local time), with the majority (24 tracks) between 2000 and 0200.

See site Y about the possible species composition of migration.

\section{REFERENCES}

ALERSTAM, T., and GUDMUNDSSON, G.A. 1999a. Migration patterns of tundra birds: Tracking radar observations along the Northeast Passage. Arctic 52:346-371.

. 1999b. Bird orientation at high latitudes: Flight routes between Siberia and North America across the Arctic Ocean. Proceedings of the Royal Society of London, B266:2499-2505.

ALERSTAM, T., and JÖNSSON, P.E. 1999. Ecology of tundra birds: Patterns of distribution, breeding and migration along the Northeast Passage. Ambio 28:212-224.

ALERSTAM, T., and PETTERSSON, S.-G. 1991. Orientation along great circles by migrating birds using a sun compass. Journal of Theoretical Biology 152:191-202.

ALERSTAM, T., HJORT, C., HÖGSTEDT, G., JÖNSSON, P.E., KARLSSON, J., and LARSSON, B. 1986. Spring migration of birds across the Greenland inland ice. Meddelelser om Grønland, Bioscience $21.38 \mathrm{p}$.

ALERSTAM, T., GUDMUNDSSON, G.A., GREEN, M., and HEDENSTRÖM, A. 2001. Migration along orthodromic sun compass routes by arctic birds. Science 291:300-303.

BATSCHELET, E. 1981. Circular statistics in biology. New York: Academic Press.

BYRKJEDAL, I., and THOMPSON, D.B.A. 1998. Tundra plovers: The Eurasian, Pacific and American golden plovers and grey plover. London: T \& AD Poyser.

DICKSON, D.L., ed. 1997. King and common eiders of the western Canadian Arctic. Canadian Wildlife Service. Occasional Paper No. 94.73 p.

EALEY, D.M., ALEXANDER, S.A., and CROFT, B. 1988. Fall migration and staging of phalaropes and other waterbirds in the vicinity of Nunaluk Spit, Yukon Territory: 1987. Alberta: Technical Report Series No. 41. Canadian Wildlife Service, Western and Northern Region.

FLOCK, W.L. 1972. Radar observations of bird migration at Cape Prince of Wales. Arctic 25:83-98.

1973. Radar observations of bird movements along the arctic coast of Alaska. Wilson Bulletin 85:259-275.

GRATTO-TREVOR, C.L. 1992. Semipalmated sandpiper Calidris pusilla. In: Poole, A., Stettenheim, P., and Gill, F., eds. The birds of North America. No. 6. Philadelphia: The Academy of Natural Sciences and The American Ornithologists' Union.

GRATTO-TREVOR, C.L., and DICKSON, D.L. 1994. Confirmation of elliptical migration in a population of semipalmated sandpipers. Wilson Bulletin 106:78-90.

GRÖNLUND, E., ed. 2000. Cruise Report, Tundra Northwest 1999. Stockholm: Swedish Polar Research Secretariat. 196 p.

GUDMUNDSSON, G.A. 1993. The spring migration of arctic birds in southwest Iceland, as recorded by radar. Ibis 135: $166-176$.

GUDMUNDSSON, G.A., and ALERSTAM, T. 1998a. Why is there no transpolar bird migration? Journal of Avian Biology 29:93-96.

1998b. Optimal map projections for analysing long-distance migration routes. Journal of Avian Biology 29:597-605.

HAIG, S.M., GRATTO-TREVOR, C.L., MULLINS, T.D., and COLWELL, M.A. 1997. Population identification of Western 
Hemisphere shorebirds throughout the annual cycle. Molecular Ecology 6:413-427.

HARRINGTON, B.A. 1996. The flight of the red knot. New York: W.W. Norton \& Company.

1999. The hemispheric globetrotting of the white-rumped sandpiper. In: Able, K.P., ed. Gathering of angels: Migrating birds and their ecology. Ithaca: Cornell University Press. 119-133.

HARRINGTON, B.A., LEEUWENBERG, F.J., LARA RESENDE, S., McNEIL, R., THOMAS, B.T., GREAR, J.R., and MARTINEZ, E.F. 1991. Migration and mass change of whiterumped sandpipers in North and South America. Wilson Bulletin 103:621-636.

HARRISON, P. 1985. Seabirds: An identification guide. London: Christopher Helm.

HOLMES, R.T., and PITELKA, F.A. 1998. Pectoral sandpiper Calidris melanotos. In: Poole, A., and Gill, F., eds. The birds of North America. No. 348. Philadelphia: The Academy of Natural Sciences and The American Ornithologists' Union.

JEHL, J.R., Jr. 1979. The autumnal migration of Baird's sandpiper. In: Pitelka, F.A., ed. Shorebirds in marine environments. Cooper Ornithological Society: Studies in Avian Biology No. 2. 55-68.

JOHNSON, O.W., and CONNORS, P.G. 1996. American goldenplover Pluvialis dominica. Pacific golden-plover Pluvialis fulva. In: Poole, A., and Gill, F., eds. The birds of North America. No. 201-202. Philadelphia: The Academy of Natural Sciences and The American Ornithologists' Union.

JOHNSON, S.R., and HERTER, D.R. 1989. The birds of the Beaufort Sea. Anchorage, Alaska: BP Exploration.

1990. Bird migration in the Arctic: A review. In: Gwinner, E., ed. Bird migration: Physiology and ecophysiology. Berlin: Springer-Verlag. 22-43.

JOHNSON, S.R., and RICHARDSON, W.J. 1982. Waterbird migration near the Yukon and Alaskan coast of the Beaufort Sea: II. Moult migration of seaducks in summer. Arctic 35:291-301.

KJELLÉN, N. 2000. Skuas on the Canadian tundra in 1999: Relative occurrence of species, ages and colour phases. Ornis Svecica 10:71-78.

KLIMA, J., and JEHL, J.R., Jr. 1998. Stilt sandpiper Calidris himantopus. In: Poole, A., and Gill, F., eds. The birds of North America. No. 341. Philadelphia: The Academy of Natural Sciences and The American Ornithologists' Union.

LAMB, H.H. 1972. Climate: Present, past and future. Vol. 1. Fundamentals and climate now. London: Methuen.

LANCTOT, R.B., and LAREDO, C.D. 1994. Buff-breasted sandpiper Tryngites subruficollis. In: Poole, A., and Gill, F., eds. The birds of North America. No.91. Philadelphia: The Academy of Natural Sciences and The American Ornithologists' Union.

McGHEE, R. 1996. Ancient people of the Arctic. Vancouver: UBC Press.

McNEIL, R., and BURTON, J. 1977. Southbound migration of shorebirds from the Gulf of St. Lawrence. Wilson Bulletin 89:167-171.

MIRSKY, J. 1970. To the Arctic! The story of northern exploration from earliest times. 3rd ed. Chicago: University of Chicago Press.

MOLAU, U., ALERSTAM, T., DANELL, K., ERIKSEN, B., and GRANÉLI, W. 1999. Tundra Northwest 1999: A collaborative challenge in the Arctic. Ambio 28:287-291.
MORRISON, R.I.G. 1984. Migration systems of some New World shorebirds. In: Burger, J., and Olla, B.L., eds. Behavior of marine animals, Vol. 6. New York: Plenum Press. 125-202.

MORRISON, R.I.G., and HARRINGTON, B.A. 1979. Critical shorebird resources in James Bay and eastern North America. Transactions of the North American Wildlife Natural Resources Conference 44:498-507.

MORRISON, R.I.G., and ROSS, R.K. 1989. Atlas of Nearctic shorebirds on the coast of South America. 2 Vols. Ottawa: Canadian Wildlife Service Special Publication.

MORRISON, R.I.G., BUTLER, R.W., BEYERSBERGEN, G.W., DICKSON, H.L., BOURGET, A., HICKLIN, P.W., GOOSEN, J.P., ROSS, R.K., and GRATTO-TREVOR, C.L. 1995. Potential Western Hemisphere Shorebird Reserve Network sites for shorebirds in Canada. 2nd ed. Canadian Wildlife Service Technical Report Series 227.

MORRISON, R.I.G., GILL, R.E., Jr., HARRINGTON, B.A., SKAGEN, S.,PAGE, G.W., GRATTO-TREVOR, C.L., andHAIG, S.M. 2001. Estimates of shorebird populations in North America. Occasional Paper 104. Ottawa: Canadian Wildlife Service. 64 p.

PARMELEE, D.F. 1992. White-rumped sandpiper Calidris fuscicollis. In: Poole, A., Stettenheim, P., and Gill, F., eds. The birds of North America. No. 29. Philadelphia: The Academy of Natural Sciences and The American Ornithologists' Union.

PAULSON, D.R. 1995. Black-bellied plover Pluvialis squatarola. In: Poole, A., and Gill, F., eds. The birds of North America. No. 186. Philadelphia: The Academy of Natural Sciences and The American Ornithologists' Union.

RICHARDSON, W.J. 1979. Southeastward shorebird migration over Nova Scotia and New Brunswick in autumn: A radar study. Canadian Journal of Zoology 57:107-124.

RICHARDSON, W.J., and JOHNSON, S.R. 1981. Waterbird migration near the Yukon and Alaskan coast of the Beaufort Sea: I. Timing, routes and numbers in spring. Arctic 34:108-121.

SALOMONSEN, F. 1967. Migratory movements of the Arctic tern (Sterna paradisaea Pontoppidan) in the Southern Ocean. Det Kongelige Danske Videnskabernes Selskab Biologiske Meddelelser 24:1-42.

SALTER, R.E., GOLLOP, M.A., JOHNSON, S.R., KOSKI, W.R., and TULL, C.E. 1980. Distribution and abundance of birds on the Arctic Coastal Plain of Northern Yukon and adjacent Northwest Territories, 1971-1976. The Canadian FieldNaturalist 94:219-238.

SAVOURS, A. 1999. The search for the Northwest Passage. New York: St. Martin's Press.

SCHLEDERMANN, P. 1996. Voices in stone: A personal journey into the Arctic past. Calgary: Arctic Institute of North America.

STODDARD, P.K., MARSDEN, J.E., and WILLIAMS, T.C. 1983. Computer simulation of autumnal bird migration over the western North Atlantic. Animal Behaviour 31:173-180.

WILLIAMS, T.C., and WILLIAMS, J.M. 1978. Orientation of transatlantic migrants. In: Schmidt-Koenig, K.M., and Keeton, W.T., eds. Animal migration, navigation and homing. Berlin: Springer-Verlag. 239-251.

. 1990. The orientation of transoceanic migrants. In: Gwinner, E., ed. Bird migration: Physiology and ecophysiology. Berlin: Springer-Verlag. 7-21. 